\title{
Direct versus Indirect Colonial Rule in India: Long- Term Consequences
}

\section{Citation}

Iyer, Lakshmi. 2010. “Direct Versus Indirect Colonial Rule in India: Long-Term Consequences." Review of Economics and Statistics 92 (4) (November): 693-713. doi:10.1162/rest_a_00023.

\section{Published Version}

doi:10.1162/REST_a_00023

\section{Permanent link}

http://nrs.harvard.edu/urn-3:HUL.InstRepos:33785664

\section{Terms of Use}

This article was downloaded from Harvard University's DASH repository, and is made available under the terms and conditions applicable to Other Posted Material, as set forth at http:// nrs.harvard.edu/urn-3:HUL.InstRepos:dash.current.terms-of-use\#LAA

\section{Share Your Story}

The Harvard community has made this article openly available.

Please share how this access benefits you. Submit a story.

Accessibility 


\title{
The Review of Economics and Statistics
}

VoL. XCII

NOVEMBER 2010

NUMBER 4

\section{DIRECT VERSUS INDIRECT COLONIAL RULE IN INDIA: LONG-TERM CONSEQUENCES}

\author{
Lakshmi Iyer*
}

Abstract-This paper compares economic outcomes across areas in India that were under direct British colonial rule with areas that were under indirect colonial rule. Controlling for selective annexation using a specific policy rule, I find that areas that experienced direct rule have significantly lower levels of access to schools, health centers, and roads in the postcolonial period. I find evidence that the quality of governance in the colonial period has a significant and persistent effect on postcolonial outcomes.

\section{Introduction}

$\mathrm{W}$ HETHER the experience of colonial rule has had a long-term impact on economic development is a topic that has generated considerable debate. Several scholars have emphasized the negative effects of colonial rule on development, citing factors such as excessive exploitation of colonies, drain of resources, or the growth of a dependency complex (see Frank, 1978, or Bagchi, 1982). Others emphasize the positive role of colonial empires in securing peace and external defense (Lal, 2004) and encouraging international trade and capital movements (Ferguson, 2002). Some authors also hold the view that resource endowments or area characteristics are the major determining forces of long-term outcomes and that colonial rule plays only a minor part (e.g., Herbst, 2000, on Africa, or Roy, 2002, on India).

I examine the colonial experience of one country, India, and compare the long-term outcomes of areas that were under direct British colonial rule with those that were under indirect colonial rule. Indirect rule in this context refers to those areas of India that were under the administration of Indian kings rather than the British Crown; these were known as the native states or the princely states. The defense and foreign policies of these native states were completely controlled by the British during the colonial period, but they enjoyed considerable autonomy in matters of internal administration. After the end of colonial rule in 1947, all of these areas were integrated into independent

Received for publication December 6, 2007. Revision accepted for publication May 1, 2009.

* Harvard Business School.

I thank two anonymous referees, Josh Angrist, Simon Johnson, Kaivan Munshi, Nathan Nunn, Rohini Pande, Marko Terviö, and numerous seminar participants for extremely helpful comments. I am grateful to Daron Acemoglu, Abhijit Banerjee, and Esther Duflo for valuable advice and guidance throughout this project, the MIT Department of Economics and the MacArthur Foundation for financial support, Esther Duflo for generously sharing her code for the randomization inference procedure, and Latika Chaudhury for data from the 1911 census.
India and have since been subject to a uniform administrative, legal, and political structure. The analysis in this paper therefore cannot answer the question of what outcomes would have been like in the complete absence of colonial rule, but it does illustrate the persistent effects of different degrees of colonial rule.

The major issue in such a comparison is, of course, the problem of selection. It is unlikely that the British randomly annexed areas for direct colonial rule. I am able to solve the selection problem by taking advantage of a unique feature of British annexation policy in India. Between 1848 and 1856 , the British governor-general, Lord Dalhousie, implemented the notorious Doctrine of Lapse, under which he refused to recognize adopted heirs and annexed several native states where the ruler died without a natural heir. This policy enables me to use the death of a ruler without an heir in the specific period of 1848 to 1856 as an instrument for becoming part of the British Empire, and thus coming under direct colonial rule. The identifying assumption here is that the death of a ruler without an heir, in this specific period of time, is likely to be a matter of circumstance and unlikely to have a direct impact on outcomes in the postcolonial period.

I find that the directly ruled British areas have significantly lower availability of public goods such as schools, health centers, and roads in the postcolonial period and are not significantly better off in terms of agricultural investments and productivity. These instrumental variable estimates, which control for selective annexation, contrast sharply with OLS results that show directly ruled British areas having significantly higher agricultural investments and productivity. This suggests strongly that the British annexed areas with the greatest agricultural potential, but did not invest as much as native states did in physical and human capital. This underinvestment is costly for development: directly ruled areas have higher levels of poverty and infant mortality in the postcolonial period.

I perform several robustness checks for my instrumental variable strategy to verify that the fact of a ruler dying without a natural heir does not have an independent effect on long-term outcomes. In particular, I conduct a falsification exercise and consider deaths of rulers without natural heirs in a different period when the Doctrine of Lapse had been officially abandoned by the British (so that death 
would not result in becoming part of the British Empire). I find no significant differences here, supporting the conclusion that it is the fact of direct colonial rule that matters for the long run rather than other aspects of historical ruler deaths.

I consider several different explanations of why we might see greater investment in human and physical capital in the indirectly ruled areas. I find that the gap between direct and indirect rule areas on these measures is narrowing over time, suggesting that differences in postcolonial institutions are unlikely to be the intervening mechanism. The differences in human capital outcomes, such as literacy, were present in the colonial period itself. I examine the operation of one specific institution, electoral democracy, and find no differences in electoral participation or the competitiveness of elections between direct and indirect rule areas in the postcolonial period.

I then examine differences in colonial period institutions and find three suggestive facts. First, native states raised higher taxes per capita than directly ruled British areas did, but this does not explain the differences in access to public goods. However, it does rule out the possibility that excessive colonial extraction is the driving mechanism. Second, local institutions, such as the prevalent land tenure system, matter for long-term outcomes only in the British areas and not in indirectly ruled areas. Third, the fact that the British retained the right to depose the native state rulers in cases of "misrule" appears to play an important role. This right was exercised quite often and thus constituted a credible threat. I find that areas where the British deposed the rulers were indeed the worst-performing ones in the sense that these areas do not show any significant advantage compared to the directly ruled British areas. Overall, this pattern of results suggests that good governance in the colonial period has persistent effects, and that directly ruled areas were on par with the least-well-governed native states.

This paper is part of a growing research program demonstrating the long-term impacts of colonial rule. The question of what outcomes would have been had European countries never established vast overseas empires is quite difficult to answer because of the potential for spillover effects from colonies to noncolonies. Most comparative research has therefore focused on the effects of different types, or "flavors," of colonial rule. Feyrer and Sacerdote (2009) find that islands with longer periods of colonial rule have better present-day outcomes; Bertocchi and Canova (2002) find that the postindependence economic performance of British colonies in Africa is less volatile than that of French and German colonies.

Several papers have examined the long-term consequences of specific institutions developed by colonial powers. These include the property rights institutions created by colonial rulers (Acemoglu, Johnson, \& Robinson, 2001), the distribution of historical property rights (Engerman \& Sokoloff, 2005; Banerjee \& Iyer, 2005), the legal systems put in place by colonial powers (La Porta et al., 1998a, 1998b; Berkowitz \& Clay, 2004), the systems of tax collection (Berger, 2008), the extent of slavery (Nunn, 2008), and colonial investments in education and health (Huillery, 2006). Some of these studies use innovative instrumental variables to get around the problem of selection. Acemoglu et al. (2001) use initial settler mortality as an instrument for the strength of property rights institutions, Feyrer and Sacerdote (2009) use wind patterns as an exogenous determinant of colonial rule, and Banerjee and Iyer (2005) rely on exogenous changes in British land policy.

The rest of the paper is organized as follows. Section II describes the British colonial experience in India and the nature of indirect colonial rule in the native states. Section III discusses why indirect rule might have different longterm consequences than direct colonial rule. Section IV briefly discusses the OLS comparisons between areas under direct and indirect rule, and section V describes the instrumental variables strategy and provides estimates of the causal impact of British rule. Section VI documents differences between areas under direct and indirect rule over time, section VII provides empirical evidence on several possible intervening mechanisms, and section VIII concludes the paper.

\section{Direct and Indirect British Colonial Rule in India}

\section{A. British India and the Native States}

The British Empire in the Indian subcontinent lasted nearly 200 years. Beginning in 1757, all the areas of present-day India, Pakistan, Bangladesh, and Burma were brought under British political control by the middle of the nineteenth century. Of this area, "British India" was defined as "all territories and places within Her Majesty's dominions which are for the time being governed by Her Majesty through the Governor-General of India."1 The remaining areas were referred to as the "native states" or the "princely states" by the colonial government and were ruled by hereditary kings. ${ }^{2}$ I will use the term native states throughout the paper.

About 680 native states were recognized by the Foreign Office in 1910. Native states constituted about $45 \%$ of the total area of British India (excluding Burma and Sind) and about $23 \%$ of the total population in 1911. The map in figure 1 shows the geographical distribution of native states. We see that native states were present in all parts of India, with somewhat higher concentrations in the western and central parts of the country.

\footnotetext{
${ }^{1}$ Interpretation Act of 1889 .

${ }^{2}$ The precise definition of a native state was a matter of some debate. Sir William Lee-Warner (1910), for instance, defined a native state as "a political community, occupying a territory in India of defined boundaries, and subject to a common and responsible ruler who has actually enjoyed and exercised, as belonging to him in his own right duly recognized by the supreme authority of the British Government, any of the functions and attributes of internal sovereignty." According to the Imperial Gazetteer (Hunter et al., 1908), a major defining feature can be said to be "the personal rule of the chief and his control over legislation and the administration of justice." In practice, this meant that "whether or not a so-called Native State is what it professes to be is a question of fact which, in the absence of a legal decision, must be settled by the present action of the British paramount power," that is, native states were those that had been recognized by the British as such.
} 


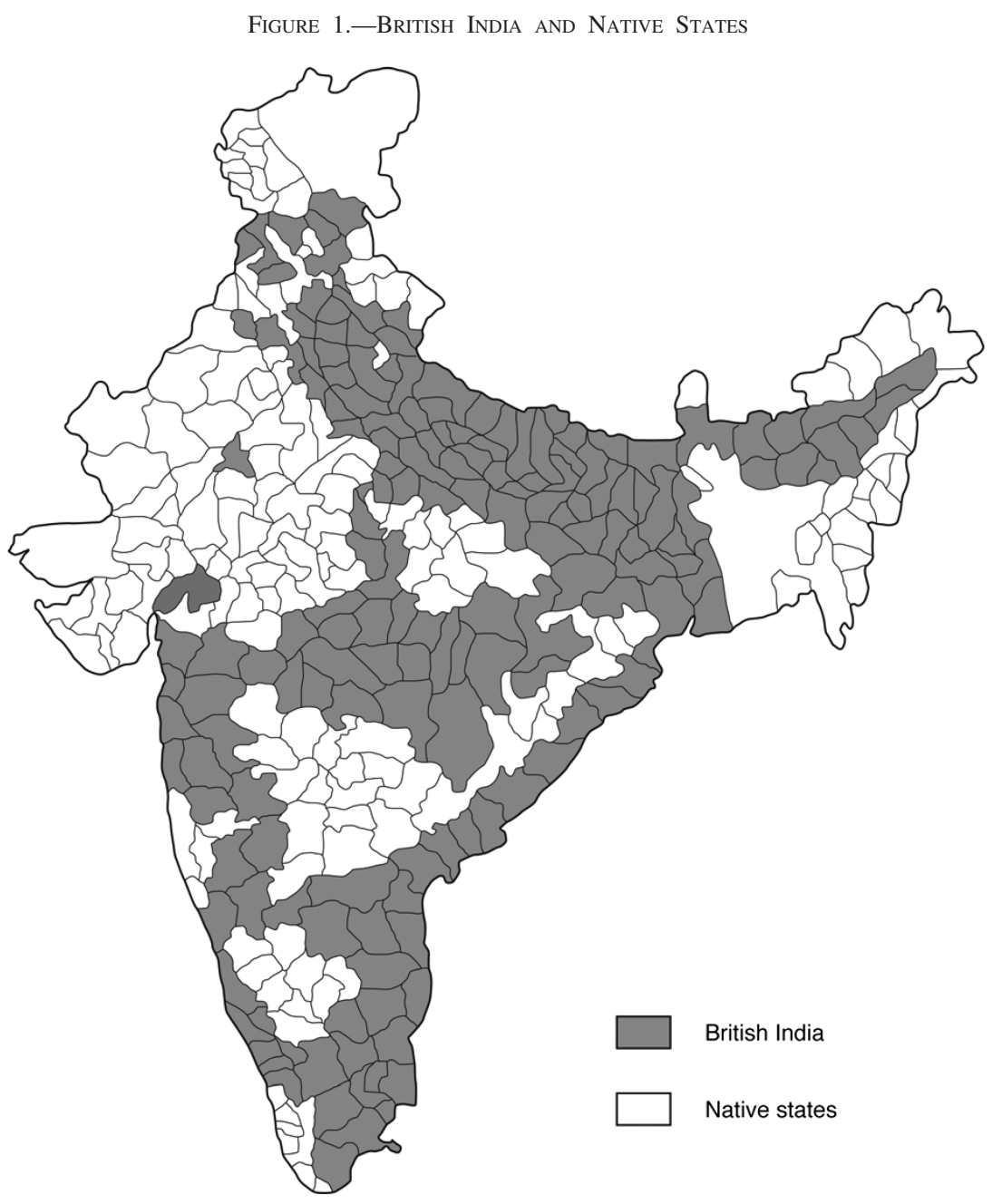

Native states varied considerably in all dimensions. Some consisted of only a few villages, while the largest native state, Hyderabad, had an area of 98,000 square miles. They had varying degrees of legal autonomy, from "first-class states," which had maximum legal powers (including that of the death penalty over their own subjects, though not over British subjects), to "third-class states," which could only try civil cases involving small sums of money. Native states also varied considerably with regard to their systems of administration and revenue collection, their currency, legal codes, law enforcement, and justice systems. Over time, some states adopted the legal codes and currency prevailing in British India. The British usually did not force them to do so but waited instead for "the willing cooperation of the Native princes." The majority of rulers were Hindu kings, though there were several Muslim and Sikh rulers as well. ${ }^{3}$

\footnotetext{
${ }^{3}$ Appendix A lists details of the major native states in our data set. In 1877, the largest and most important states were designated by the British as "salute states," meaning that the rulers were entitled to a ceremonial gun salute. The table lists the native states in order of the number of guns in the salute, reflecting their importance in the eyes of the British.
}

\section{B. British Policy toward the Native States}

The British did not bring the whole Indian subcontinent under direct colonial rule mainly because of a major policy change in the nineteenth century. After the Sepoy mutiny of 1857, the British stopped all further annexation of native states into the British Empire. British policy toward the native states underwent considerable changes over time, from the policy of the ring fence (1765-1818), to that of subordinate isolation (1818-1858), to that of nonannexation with the right of intervention (1858-1947).

The Ring Fence. In initial period of British rule (17651818), the East India Company did not wish to annex too much territory under its own administration, because it was numerically and politically weak and because it wanted to maintain a "ring fence" between its areas and the stronger empires of the Marathas and the Sikhs. Despite this policy of nonintervention, the East India Company annexed a number of areas during this period, mostly by fighting and winning wars against Indian rulers (table 1). Several 
TABle 1.-Growth of THE BRITISH EMPIRE IN INDIA

\begin{tabular}{cccccc}
\hline \hline \multirow{2}{*}{ Period } & \multicolumn{2}{c}{ Number of Districts Annexed and Reason } & \\
\cline { 2 - 4 } & Conquest & Ceded or Granted & Misrule & Lapse & Total \\
\hline $1757-1790$ & 60 & 19 & 0 & 0 & 79 \\
$1791-1805$ & 46 & 37 & 1 & 0 & 84 \\
$1806-1818$ & 29 & 0 & 0 & 0 & 29 \\
$1819-1835$ & 20 & 0 & 1 & 0 & 21 \\
$1836-1847$ & 19 & 0 & 1 & 1 & 21 \\
$1848-1856$ & 2 & 4 & 12 & 16 & 34 \\
$1857-1947$ & 0 & 1 & 0 & 0 & 1 \\
Total & 176 & 61 & 15 & 17 & 269 \\
\hline
\end{tabular}

Note: Number of districts refers to 1991 districts. The total number of districts is 415 , of which 269 were classified as belonging to British India. The states of Manipur, Meghalaya, Mizoram, Nagaland, Sikkim, and Tripura are excluded from the study. The number of districts in subsequent regressions will be below 415 due to missing data and because some districts were split into two or more new districts over time; also some data sets use older unsplit districts. The one district added after 1858 is over time; also some data sets use older unsplit districts. The one district added after 1858 is
Panchmahals, which was ceded by the ruler of Gwalior to the British in exchange for some other territory.

territories were also ceded or granted to the British by native rulers, usually for nonpayment of debts or tribute.

Subordinate Isolation. In 1817-1818, after winning a series of battles in central India, the British emerged as the dominant political power in the subcontinent. The East India Company now followed the policy of subordinate isolation: all native states were made politically subordinate to the British and accepted the British as the "paramount power" in India. They could not declare war, establish relations with other states, or employ Europeans without explicit British permission. Many of them signed treaties with the British that regulated the size of their armed forces, and several native states had British forces stationed within their territory. Most of the native states also had annual tribute obligations to the British government (or in some cases to another native state): for the native states in our data set, the tribute varied from 0 to $28 \%$ of state revenue. However, they were allowed considerable autonomy in internal matters unless they had specific treaty provisions. ${ }^{4}$

Between 1818 and 1848, the East India Company continued annexing territory by various means. The pace of British annexation picked up considerably after Lord Dalhousie became governor-general in 1848. In addition to fighting the second Sikh war in Punjab, Lord Dalhousie also annexed areas by taking over territories due to nonpayment of debts (Berar), accusing the native rulers of "misrule" (Oudh), and, most controversial, refusing to recognize adoptions and annexing areas where the native ruler died without a natural heir (the so-called policy of lapse).

End of Annexation. In 1857, Indian soldiers in the British army mutinied against their officers. The causes of this Sepoy mutiny are not very clear, and historians disagree as to whether it was a planned war of independence against British power or an uncoordinated uprising of soldiers who

\footnotetext{
${ }^{4}$ These could be explicit restrictions, such as the ruler of Panna being asked to abolish the practice of sati (widow burning) in his kingdom, or more general ones, such as the ruler of Oudh being required to implement policies that "shall be conducive to the prosperity of his subjects, and be calculated to secure the lives and property of the inhabitants."
}

felt a threat to their religion and traditional practices (Spear, 2002), or simply a mutiny by soldiers who wanted increased pay and greater career opportunities (David, 2002). After some initial reverses, the British rallied and were able to suppress the mutiny by the end of 1858 .

After this major shock to British power, the administration of India was taken over by the British Crown from the East India Company in 1858. Many native states had aided the British during the mutiny by supplying troops and equipment or by defending the Europeans within their territory. As a recognition of this, plans of further annexation were given up, with the queen's proclamation of 1858 stating specifically, "We desire no extension of our present territorial possessions." Thus, the areas that had not been annexed until 1858 continued to be native states until the end of British rule in 1947.

Although the British gave up outright annexation of territory, they reserved the right to intervene in the internal affairs of native states "to set right such serious abuses in a Native Government as may threaten any part of the country with anarchy or disturbance." 5 They exercised this right in several native states, often by deposing the ruler and installing another in his place (usually a son, brother, cousin, or adopted heir) or by appointing a British administrator or council of regency for some time before allowing the king to take up ruling powers again. ${ }^{6}$

\section{Native States in Independent India}

When the British left India in 1947, all native states signed treaties of accession to the newly independent nations of India or Pakistan, sometimes under the threat of military action. By 1950, all of the native states within the borders of India had been integrated into independent India and were subject to the same administrative, legal, and political systems as those of the erstwhile British Indian areas. The rulers of these states were no longer sovereign rulers, but many of them continued to play an active role in the politics of postindependence India. They were granted annual incomes, referred to as privy purses, by the Indian government as partial compensation for their loss of state revenue, but this privilege, along with all other princely honors, was discontinued in 1971.

\section{Why Might Direct Colonial Rule Matter for Long-Term Outcomes?}

Why should areas directly ruled by a colonial power have different long-run outcomes compared to areas ruled indirectly by local rulers? I consider two broad types of mechanisms. The first is that differences in historical circum-

\footnotetext{
${ }^{5}$ Lord Canning, Government of India Foreign Department Despatch No. 43A to S/S, April 30, 1860.

${ }^{6}$ Different viceroys used this power to intervene in different degrees. One of the most vigorous in this regard was Lord Curzon, viceroy from 1899 to 1905 , during whose tenure fifteen rulers were either forced to abdicate or temporarily deprived of their powers (Ashton, 1982).
} 
stances might affect postcolonial policies or the functioning of modern institutions and therefore lead to differences in postcolonial outcomes. This has been shown in other studies, such as the greater propensity of historically unequal Indian states to enact land reforms (Banerjee \& Iyer, 2005) or the functioning of the legal system across different U.S. states (Berkowitz \& Clay, 2004).

In terms of direct and indirect rule, one potential institutional difference is likely to be in the operation of democratic processes. Members of the erstwhile ruling families of the native states continued to be active in the politics of postcolonial India, with several former princes being elected to national and state-level political office (Allen \& Dwivedi, 1998). Such candidates have significant electoral advantages in terms of higher name recognition, strong ties with the local elites, and greater resources. Their presence in politics may result in higher voter participation and a more informed electorate, and therefore greater pressure on political representatives to deliver public goods. ${ }^{7}$

I check for the presence of such policy effects by running regressions with state fixed effects in section VE. I then provide evidence in section VI strongly suggesting that the differences arose mainly in the colonial period and are narrowing in the postcolonial period. I also directly test the political channel using data from postcolonial elections on voter turnout and measures of electoral competitiveness.

The second class of explanations focuses on differences arising due to colonial policies. One potential hypothesis is that colonial rulers might set up poor institutions in places where they do not intend to settle over the long term. For instance, property rights may be poorly protected, or there might be an insufficient focus on investments that primarily benefit the local population rather than the colonial power. ${ }^{8}$ This is very plausible in the Indian context, because the British did not settle in India in large numbers: as late as 1911, the proportion of Christians in India was less than $1.3 \%$ of the population. Presumably indirectly ruled areas, with rulers who belonged to that region, were likely to make better institutional choices.

I test this hypothesis by focusing on one important institution: the land revenue system. Land revenue was the largest source of government revenue for both British India and the native states. Banerjee and Iyer (2005) have shown that areas with landlord-based revenue systems, where land-

\footnotetext{
${ }^{7}$ There are two offsetting factors to this. First, higher electoral advantages may translate into lower incentives for politicians to actually deliver public goods, and, second, areas under direct British rule had a longer experience with democratic processes, since provincial elections had been held in these areas during the colonial period following the Government of India Act of 1935. An early study by Richter (1975) finds lower voter turnout and higher victory margins for candidates in native state constituencies in the elections of 1957, 1962, and 1967. However, this analysis does not control for omitted variables or selection into direct rule.

${ }^{8}$ Several previous studies have highlighted the role of such factors. Acemoglu et al. (2001) find that colonies where settlement was deterred by the disease environment have poorer indicators of property rights protection, and Feyrer and Sacerdote (2009) find that Pacific islands that were colonized during the era of Enlightenment have better outcomes in the long run.
}

lords were in charge of revenue collection, have worse long-run outcomes compared to places with cultivatorbased systems, where the ruler collected the revenue directly from the cultivators. The former system resulted in greater land inequality and could indirectly have led to worse governance by the colonial state, since most of the gains of any productivity improvements would be captured by the landlords. ${ }^{9}$ This paper differs in two important ways: the analysis of Banerjee and Iyer (2005) does not include the indirectly ruled areas, and they find that the primary channel of influence is through the impact of historical institutions on postcolonial policy. In section VII, I extend the analysis to include indirectly ruled areas and find a much more nuanced result.

A second version of the extractive institutions hypothesis is that colonial rulers might resort to excessive taxation as part of a strategy to extract the colony's resources to the benefit of the colonial power and that they might be able to do this more effectively in directly ruled areas. In India, Mukherjee (1972) estimates the extent of economic drain from India to Britain to be of the order of $0.04 \%$ to $0.07 \%$ of national income over the period 1840 to 1900 , which is not very large. British colonial rulers also imposed significant tribute obligations on the native states, so it is not clear that the burden of drain would be different across the two types of areas. I explicitly compare tax collections across British areas and the native states and examine whether this can explain the differences in long-term outcomes.

A third possibility is that the rulers of native states had better incentives, compared to British administrators, to provide public goods to their subjects. The historical record indicates two key institutional differences. First, native states rulers had much longer tenures than British administrators, which might play a role in undertaking long-term investments such as schools or health facilities. ${ }^{10}$ The natives states in our data set had, on average, between four and five kings over the period 1858 to 1947, while British India was ruled by 24 different governors-general. Lower-level administrators had even higher rates of turnover: in 1936, two-thirds of district officers in British India had held their posts for less than one year (Potter, 1996). Second, as described in section IIB, the British reserved the right to depose native state rulers if they governed badly enough to provoke widespread protest. This was a credible threat: 21 of the 71 native states in our data set had their king deposed in the period 1858 to 1947 . They were usually replaced by a relative (brother, son, cousin), but this would still mean a significant diminution in wealth and personal status for the

\footnotetext{
${ }^{9}$ This is particularly the case for landlord-based areas where revenue commitments to the British colonial rulers had been fixed in perpetuity, leaving the landlords as residual claimants. Banerjee and Iyer (2005) also document other channels through which this historical institution plays a role.

${ }^{10}$ Some empirical work in other settings support this hypothesis. Rauch (1995) demonstrates that city mayors in the United States with longer tenures have a higher likelihood of undertaking long-term infrastructure projects, while Do and Iyer (2008) show that Vietnamese farmers who are assured of a longer tenure on their land are more likely to plant long-term crops.
} 
previous king. British administrators were promoted on the basis of seniority (Das, 2001); the usual penalty for bad performance was transfer to another district. ${ }^{11}$ In section VII, I test whether the quality of governance during the colonial period matters for long-term outcomes by testing whether outcomes vary across native states whose rulers were deposed for misrule and those whose rulers were never deposed.

\section{Comparing Areas under Direct and Indirect Rule}

\section{A. Data}

I compare outcomes across British India and native state areas using district-level data from the postindependence period. A district in India is an administrative division below state level. In 1991, India had 415 districts in seventeen major states, ${ }^{12}$ a district on average having an area of 7,500 square kilometers and a population of 1.5 million. The major reason I use district-level data is that for each modern district, I am able to use old and new maps to find out whether it was part of the British Empire or a native state as of 1947. This is much harder to do for state-level data because modern state boundaries in India are completely different from older native state or British province boundaries, mainly due to the 1956 reorganization of states on a linguistic basis.

For each district, I create a British dummy, which equals 1 if the district was formerly part of British India. Some modern districts comprise several native states, and some native states were large enough to extend over several modern districts. A few districts contain areas from both the British Empire and the native states, in which case the British dummy is assigned to be 1 if the major part of the district belonged to the British Empire. This will be the main independent variable in the analysis.

One major drawback of district-level data in India is the absence of data on per capita income, consumption, or net domestic product (these are available only at the state level). I therefore conduct my analysis using other proxies for economic well-being. The major outcomes I consider are measures of agricultural investment and productivity (agriculture accounted for $37 \%$ of India's total GDP and $67 \%$ of the working population in 1981); the availability of public goods such as schools, health centers, and roads; and health and education outcomes. In addition, I analyze data on the relative size of the manufacturing sector in district employment, as well as district-level poverty estimates from Topalova (2005). Data sources are listed in appendix B.

\footnotetext{
${ }^{11}$ In fact, Potter (1996) cites the incompetence of officers as one of the reasons for the relatively short tenure of officers in a given district.

${ }^{12}$ The states in our analysis are Andhra Pradesh, Assam, Bihar, Gujarat, Haryana, Himachal Pradesh, Jammu and Kashmir, Karnataka, Kerala, Madhya Pradesh, Maharashtra, Orissa, Punjab, Rajasthan, Tamil Nadu, Uttar Pradesh, and West Bengal. These states accounted for $96 \%$ of India's population in 2001.
}

\section{B. OLS Estimates of the Impact of Direct Colonial Rule}

I first run OLS regressions of the form

$$
y_{i}=\alpha+\beta \text { Brit }_{i}+\gamma X_{i}+\epsilon_{i},
$$

where $y_{i}$ is an outcome variable for district $i$, Brit $_{i}$ is a dummy for whether the district was part of the (directly ruled) British Empire, and $X_{i}$ are other district characteristics (mainly geography). Since some native states extended over several districts and the main dependent variable Brit $_{i}$ is assigned at the native state level, I compute standard errors clustered at the level of the native state to take into account possible correlation in outcomes across districts that used to be part of the same native state..$^{13}$

The regression in equation (1) may not indicate a causal effect of having direct British rule, because the main dependent variable, $\mathrm{Brit}_{i}$, is potentially endogenous. For instance, if it were the case that the British annexed the areas with the most potential for agricultural productivity, then the OLS regression would yield an overestimate of the causal impact of British rule. It is also possible that only the most unproductive areas came under British rule (because local rulers did not put much effort in defending these areas). In this case, the OLS regression provides an underestimate of the impact of direct British rule.

In fact, we see that areas annexed to the British Empire have significantly higher rainfall and a significantly lower proportion of barren or rocky areas, compared to areas that were part of native states (table 2). This suggests that British annexation policy was selective and geared toward picking out the areas that were likely to be more favorable to agriculture. There are no significant differences in other geographic characteristics such as latitude, altitude, or major soil types. I will be controlling for geographic variables in all the regressions, but these differences could indicate the presence of other unobserved differences, which might bias the OLS estimates.

To identify the causal impact of direct rule, I need an exogenous determinant of annexation. For this, I make use of Lord Dalhousie's Doctrine of Lapse, according to which the British would take over a native state if its ruler died without a natural heir. I argue that this is a plausibly exogenous determinant of whether a district became part of the British Empire and use this as an instrument to estimate the impact of British rule. Before describing this strategy in detail in section V, I briefly discuss the results from the estimation of equation (1).

\section{Does the Mode of Annexation Matter?}

A simple comparison of British areas with native state areas suggests that British areas have significantly higher

\footnotetext{
${ }^{13}$ For British Empire areas, "native states" for the purpose of clustering are assigned according to region and date of annexation. For instance, all areas annexed from Mysore after the 1792 Mysore War are grouped together as belonging to the same native state.
} 
TABle 2.-DifFERENCES IN GeOgRaPhy AND DEMOGRaphics

\begin{tabular}{|c|c|c|c|c|c|}
\hline \multirow[b]{2}{*}{ Variable } & \multirow{2}{*}{$\begin{array}{c}\text { Number of } \\
\text { Districts }\end{array}$} & \multirow{2}{*}{$\begin{array}{c}\text { Number of } \\
\text { Native States }\end{array}$} & \multicolumn{2}{|c|}{ Mean } & \multirow{2}{*}{$\begin{array}{l}\text { Difference } \\
\quad \text { (s.e.) }\end{array}$} \\
\hline & & & British Empire & Native States & \\
\hline \multicolumn{6}{|l|}{ Geography } \\
\hline Latitude (degrees north) & 407 & 98 & 23.29 & 22.79 & $\begin{array}{c}0.509 \\
(1.813)\end{array}$ \\
\hline Altitude (meters above sea level) & 359 & 92 & 392.63 & 413.27 & $\begin{array}{c}-20.64 \\
(58.73)\end{array}$ \\
\hline Mean annual rainfall (mm) & 414 & 98 & 1503.41 & 1079.16 & $\begin{array}{l}424.35^{* * * *} \\
(151.08)\end{array}$ \\
\hline Coastal district (dummy) & 415 & 98 & 0.1264 & 0.0822 & $\begin{array}{c}0.0442 \\
(0.0597)\end{array}$ \\
\hline Proportion sandy & 378 & 96 & 0.0079 & 0.0117 & $\begin{array}{c}-0.0038 \\
(0.0074)\end{array}$ \\
\hline Proportion barren/rocky & 378 & 96 & 0.0050 & 0.0121 & $\begin{array}{c}-0.0070 * * \\
(0.0028)\end{array}$ \\
\hline \multicolumn{6}{|l|}{ Top soil types } \\
\hline Black soil (dummy) & 362 & 93 & 0.1568 & 0.2937 & $\begin{array}{c}-0.1369 \\
(0.1075)\end{array}$ \\
\hline Alluvial soil (dummy) & 362 & 93 & 0.5254 & 0.4921 & $\begin{array}{c}0.0334 \\
(0.1301)\end{array}$ \\
\hline Red soil (dummy) & 362 & 93 & 0.2203 & 0.0952 & $\begin{array}{c}0.1251 \\
(0.0776)\end{array}$ \\
\hline \multicolumn{6}{|l|}{ Demographic variables } \\
\hline Log (population) & 323 & 93 & 14.42 & 13.83 & $\begin{array}{l}0.591 \text { *** } \\
(0.155)\end{array}$ \\
\hline Population density (persons $/ \mathrm{km}^{2}$ ) & 322 & 93 & 279.47 & 169.20 & $\begin{array}{l}110.27 * * \\
(41.66)\end{array}$ \\
\hline Proportion rural & 323 & 93 & 0.8210 & 0.8182 & $\begin{array}{c}0.0028 \\
(0.0154)\end{array}$ \\
\hline Proportion of working population in farming & 323 & 93 & 0.6961 & 0.7072 & $\begin{array}{c}-0.0111 \\
(0.0239)\end{array}$ \\
\hline Proportion scheduled caste & 323 & 93 & 0.1567 & 0.1512 & $\begin{array}{c}0.0055 \\
(0.0148)\end{array}$ \\
\hline Proportion scheduled tribe & 323 & 93 & 0.0859 & 0.0973 & $\begin{array}{c}-0.0114 \\
(0.0271)\end{array}$ \\
\hline Proportion literate & 323 & 93 & 0.3234 & 0.2867 & $\begin{array}{c}0.0367 \\
(0.0283)\end{array}$ \\
\hline
\end{tabular}

agricultural investments and productivity in the postcolonial period and slightly lower levels of infrastructure at the village level, such as schools, health centers, canals, and roads (tables 3 and 4). Each entry in table 3 and table 4 represents the coefficient from a regression of the form (1) for the listed dependent variables (for example, irrigation, fertilizer). Over the period 1956 to 1987, former British Empire areas had a higher proportion of irrigated area, greater fertilizer use, faster adoption of high-yielding varieties, and, consequently, higher agricultural yields. Breaking out the results by mode of annexation employed suggests that the selective annexation story might be relevant: areas annexed through either cession, misrule, or conquest do better than areas annexed due to lapse, or death of a native ruler without an heir. We find a similar trend for the results on village-level infrastructure. Although the differences are generally not statistically significant, areas annexed by means of lapse have significantly lower levels of most of these infrastructure variables (table 4). All the results are very similar when I use the number of years under direct British rule as the main independent variable rather than a dummy for British rule. ${ }^{14}$

\section{IV Estimates of the Impact of Direct Colonial Rule}

\section{A. Does the Period of Annexation Matter?}

Places that came under direct British rule are likely to be systematically different from places that did not. This is likely to be of greater significance for early annexations, since they were mainly annexed by conquest, for which the British had to expend considerable resources. As a first step toward controlling for this selectivity in annexation, I compare areas that were annexed by the British toward the end of the annexation period (on or after 1848) with those that were never annexed. In this period, many of the annexations were not by conquest, and hence the selection bias is likely to be smaller than in the full sample. I find that the directly

\footnotetext{
14 The number of years under direct British rule is highly correlated with the British dummy; the correlation coefficient is 0.84 .
} 
Table 3.-Differences in Agricultural InVestments and Productivity: OLS Estimates

\begin{tabular}{|c|c|c|c|c|c|c|c|}
\hline & \multicolumn{2}{|c|}{ British Dummy } & \multicolumn{4}{|c|}{$\begin{array}{l}\text { British Dummy Interacted with Mode of } \\
\text { Annexation }\end{array}$} & \multirow{3}{*}{$\begin{array}{c}\begin{array}{c}\text { Years of Direct } \\
\text { British Rule } \\
(\times 1 / 100)\end{array} \\
(4)\end{array}$} \\
\hline & \multirow{2}{*}{$\begin{array}{l}(1) \\
\text { No Controls }\end{array}$} & \multirow{2}{*}{$\begin{array}{c}(2) \\
\text { Geography Controls }\end{array}$} & \multicolumn{4}{|c|}{ (3) } & \\
\hline & & & Conquest & Ceded & Misrule & Lapse & \\
\hline \multicolumn{8}{|l|}{ Dependent variables (1956-1987 mean) } \\
\hline \multirow[t]{2}{*}{ Proportion of area irrigated } & $0.111 * * *$ & $0.099 * * *$ & 0.069 & $0.152 * * *$ & $0.113 * *$ & 0.062 & $0.079 * * *$ \\
\hline & $(0.039)$ & $(0.037)$ & $(0.051)$ & $(0.043)$ & $(0.047)$ & $(0.046)$ & $(0.024)$ \\
\hline \multirow[t]{2}{*}{ Fertilizer usage (kg/hectare) } & $8.428 * *$ & $7.014 * *$ & 4.943 & $10.542 * * *$ & $13.731 * *$ & -1.485 & $5.563^{* * *}$ \\
\hline & $(3.541)$ & $(3.073)$ & $(4.308)$ & $(2.803)$ & $(5.741)$ & $(2.717)$ & $(1.910)$ \\
\hline \multirow{2}{*}{$\begin{array}{l}\text { Proportion of cereal area sown with } \\
\text { high-yielding varieties }\end{array}$} & $0.074^{* *}$ & $0.066 * *$ & 0.046 & $0.103 * * *$ & $0.073 * *$ & $0.041^{*}$ & $0.053 * * *$ \\
\hline & $(0.034)$ & $(0.028)$ & $(0.039)$ & $(0.033)$ & $(0.035)$ & $(0.022)$ & $(0.019)$ \\
\hline \multirow[t]{2}{*}{ Log total yield (15 major crops) } & $0.381 * * *$ & $0.213 * * *$ & $0.210 * *$ & $0.236^{* *}$ & $0.282 * * *$ & 0.076 & $0.194 * * *$ \\
\hline & $(0.121)$ & $(0.080)$ & $(0.103)$ & $(0.112)$ & $(0.077)$ & $(0.092)$ & $(0.051)$ \\
\hline \multirow[t]{2}{*}{ Log rice yield } & 0.135 & $0.151 *$ & $0.220 * *$ & 0.106 & $0.128 *$ & -0.023 & $0.135 * *$ \\
\hline & $(0.112)$ & $(0.083)$ & $(0.106)$ & $(0.096)$ & $(0.077)$ & $(0.090)$ & $(0.056)$ \\
\hline \multirow[t]{2}{*}{ Log wheat yield } & -0.002 & -0.064 & -0.017 & -0.076 & $-0.133^{*}$ & -0.185 & -0.006 \\
\hline & $(0.170)$ & $(0.088)$ & $(0.091)$ & $(0.104)$ & $(0.072)$ & $(0.204)$ & $(0.057)$ \\
\hline \multicolumn{8}{|l|}{ Controls } \\
\hline Latitude, rainfall, coast & No & Yes & \multicolumn{4}{|c|}{ Yes } & Yes \\
\hline Proportion sandy/barren & No & Yes & \multicolumn{4}{|c|}{ Yes } & Yes \\
\hline Soil type dummies & No & Yes & \multicolumn{4}{|c|}{ Yes } & Yes \\
\hline Number of districts & 271 & 271 & \multicolumn{4}{|c|}{271} & 271 \\
\hline Number of native states & 83 & 83 & \multicolumn{4}{|c|}{83} & 83 \\
\hline
\end{tabular}

ruled areas no longer have any significant agricultural advantages and continue to have slightly lower levels of public goods provision (see tables 7 and 8 , column 3 ). This suggests that selection bias is likely to be a major confounding factor. I now construct instrumental variable estimates as a more precise way to control for the selectivity in annexation.

\section{B. Doctrine of Lapse}

Lord Dalhousie, governor-general of India from 1848 to 1856, articulated an unusual policy of annexation in 1848: "I hold that on all occasions where heirs natural shall fail, the territory should be made to lapse and adoption should not be permitted, excepting in those cases in which some strong political reason may render it expedient to depart from this general rule." He used this policy to annex several states where Indian rulers died without a natural heir. Eight native states (comprising twenty modern districts) had rulers die without a natural heir during the governorship of Lord Dalhousie. Of these, four native states (Satara, Sambalpur, Jhansi, and Nagpur), comprising sixteen districts, were successfully annexed. The other four did not become part of the British Empire due to various reasons: the annexation of Ajaigarh was reversed by Dalhousie's successor, Lord Canning; the annexation of Karauli was disallowed by the East India Company's court of directors; Orccha was allowed to adopt an heir because of a prior agreement; and in Chhatarpur, a nephew of the king, was allowed to succeed. ${ }^{15}$ We should note that in each of these

\footnotetext{
15 The historical details are presented in appendix C.
}

cases, Lord Dalhousie recommended applying the policy of lapse, so the fact that these areas were ultimately not annexed was not a result of Dalhousie's selectively applying the policy of lapse but of factors beyond his control.

Of the remaining 65 native states (161 districts) where such a lapse did not occur, Lord Dalhousie annexed only 3 (18 districts). These were the states of Punjab, Berar, and Oudh, which were annexed by means of conquest, nonpayment of debt, and misrule, respectively. ${ }^{16}$ The policy of lapse thus meant that areas where the ruler died without a natural heir had a higher probability of being annexed. This is confirmed by our first-stage regressions, which are discussed in detail in section VC.

Lord Dalhousie's policy was in contrast to the policies followed by several earlier British administrators who recognized adoptions by native rulers. In fact, rulers dying without natural heirs was not an unusual occurrence during this century. For instance, table 5 shows that in the period 1835 to 1847 (immediately before Dalhousie came to India), fifteen rulers died without natural heirs, but only one of these states was annexed. This meant that Dalhousie's policy was an unexpected event for the native states; not surprisingly, it was extremely unpopular among the native rulers. This policy was withdrawn when the British Crown took over the administration in 1858; in fact, official documents guaranteeing British recognition of adopted heirs were sent out to native rulers to

\footnotetext{
${ }^{16}$ Lord Dalhousie also annexed the small states of Jaitpur, Udaipur, and Baghat, of which the latter two annexations were reversed by Lord Canning.
} 
Table 4.-Differences in Public Goods Levels: OLS Estimates

\begin{tabular}{|c|c|c|c|c|c|c|c|c|}
\hline & \multicolumn{3}{|c|}{ British Dummy } & \multicolumn{4}{|c|}{ British Dummy Interacted with Mode of Annexation } & \multirow{3}{*}{$\begin{array}{c}\begin{array}{c}\text { Years of Direct } \\
\text { British Rule } \\
(\times 1 / 100)\end{array} \\
(5)\end{array}$} \\
\hline & (1) & (2) & (3) & & & (4) & & \\
\hline & No Controls & Controls & Soil Controls & Conquest & Ceded & Misrule & Lapse & \\
\hline \multicolumn{9}{|c|}{ Dependent variables: Proportion of villages having public goods (mean of 1981 and 1991 data) } \\
\hline Primary school & $\begin{array}{c}-0.035 \\
(0.039)\end{array}$ & $\begin{array}{r}-0.016 \\
(0.032)\end{array}$ & $\begin{array}{c}-0.007 \\
(0.032)\end{array}$ & $\begin{array}{c}0.035 \\
(0.037)\end{array}$ & $\begin{array}{c}-0.121 * * * \\
(0.042)\end{array}$ & $\begin{array}{c}-0.062^{* *} \\
(0.028)\end{array}$ & $\begin{array}{r}-0.007 \\
(0.029)\end{array}$ & $\begin{array}{c}-0.027 \\
(0.022)\end{array}$ \\
\hline Middle school & $\begin{array}{c}-0.035 \\
(0.046)\end{array}$ & $\begin{array}{c}-0.046 \\
(0.034)\end{array}$ & $\begin{array}{c}-0.033 \\
(0.035)\end{array}$ & $\begin{array}{c}-0.008 \\
(0.043)\end{array}$ & $\begin{array}{c}-0.106^{* * * *} \\
(0.038)\end{array}$ & $\begin{array}{c}-0.077 * * * \\
(0.027)\end{array}$ & $\begin{array}{c}-0.085 * * * \\
(0.031)\end{array}$ & $\begin{array}{c}-0.050 * * \\
(0.023)\end{array}$ \\
\hline High school & $\begin{array}{c}-0.045 \\
(0.049)\end{array}$ & $\begin{array}{c}-0.068^{*} \\
(0.040)\end{array}$ & $\begin{array}{c}-0.059 \\
(0.038)\end{array}$ & $\begin{array}{c}-0.041 \\
(0.045)\end{array}$ & $\begin{array}{c}-0.112 * * \\
(0.043)\end{array}$ & $\begin{array}{c}-0.096^{* * * *} \\
(0.034)\end{array}$ & $\begin{array}{c}-0.081^{* *} \\
(0.037)\end{array}$ & $\begin{array}{c}-0.061 * * \\
(0.026)\end{array}$ \\
\hline Primary health center & $\begin{array}{c}-0.010 \\
(0.017)\end{array}$ & $\begin{array}{c}-0.024 * \\
(0.014)\end{array}$ & $\begin{array}{r}-0.019 \\
(0.013)\end{array}$ & $\begin{array}{c}-0.018 \\
(0.016)\end{array}$ & $\begin{array}{c}-0.036^{* * *} \\
(0.017)\end{array}$ & $\begin{array}{c}-0.023^{*} \\
(0.013)\end{array}$ & $\begin{array}{c}-0.029 * * \\
(0.012)\end{array}$ & $\begin{array}{c}-0.022 * * \\
(0.010)\end{array}$ \\
\hline Primary health subcenter & $\begin{array}{c}0.006 \\
(0.017)\end{array}$ & $\begin{array}{r}-0.002 \\
(0.017)\end{array}$ & $\begin{array}{c}0.005 \\
(0.017)\end{array}$ & $\begin{array}{c}0.017 \\
(0.021)\end{array}$ & $\begin{array}{r}-0.033^{*} \\
(0.018)\end{array}$ & $\begin{array}{c}0.005 \\
(0.013)\end{array}$ & $\begin{array}{c}-0.037 * * \\
(0.015)\end{array}$ & $\begin{array}{c}-0.002 \\
(0.012)\end{array}$ \\
\hline Canals & $\begin{array}{c}-0.028 \\
(0.021)\end{array}$ & $\begin{array}{c}-0.010 \\
(0.014)\end{array}$ & $\begin{array}{c}-0.011 \\
(0.014)\end{array}$ & $\begin{array}{c}-0.001 \\
(0.016))\end{array}$ & $\begin{array}{c}-0.021 \\
(0.014)\end{array}$ & $\begin{array}{c}-0.029 * * \\
(0.013)\end{array}$ & $\begin{array}{c}-0.022 * \\
(0.013)\end{array}$ & $\begin{array}{c}-0.005 \\
(0.010)\end{array}$ \\
\hline Roads & $\begin{array}{c}0.028 \\
(0.072)\end{array}$ & $\begin{array}{c}0.043 \\
(0.065)\end{array}$ & $\begin{array}{c}0.077 \\
(0.064)\end{array}$ & $\begin{array}{c}0.066 \\
(0.095)\end{array}$ & $\begin{array}{c}0.033 \\
(0.051)\end{array}$ & $\begin{array}{c}0.097 * \\
(0.055)\end{array}$ & $\begin{array}{c}-0.113 * * \\
(0.044)\end{array}$ & $\begin{array}{r}-0.007 \\
(0.053)\end{array}$ \\
\hline Combined public goods & $\begin{array}{c}-0.017 \\
(0.029)\end{array}$ & $\begin{array}{r}-0.017 \\
(0.025)\end{array}$ & $\begin{array}{c}-0.006 \\
(0.025)\end{array}$ & $\begin{array}{c}0.008 \\
(0.033)\end{array}$ & $\begin{array}{c}-0.057 * * \\
(0.023)\end{array}$ & $\begin{array}{c}-0.026 \\
(0.018)\end{array}$ & $\begin{array}{c}-0.055^{* * *} \\
(0.018)\end{array}$ & $\begin{array}{c}-0.024 \\
(0.017)\end{array}$ \\
\hline \multicolumn{9}{|l|}{ Controls } \\
\hline Latitude, rainfall, coast & No & Yes & Yes & & & Yes & & Yes \\
\hline Proportion sandy/barren & No & Yes & Yes & & & Yes & & Yes \\
\hline Soil type dummies & No & No & Yes & & & No & & No \\
\hline Number of districts & 404 & 377 & 340 & & & 377 & & 377 \\
\hline Number of native states & 97 & 96 & 92 & & & 96 & & 96 \\
\hline
\end{tabular}

Note: Robust standard errors in parentheses, corrected for clustering within native states.

*Significant at $10 \%$.

**Significant at $5 \%$.

$* * *$ Significant at $1 \%$

Each cell represents the coefficient from an OLS regression of the dependent variable on the independent variable, which is a dummy for British rule in columns 1-3, the dummy interacted with other variables in columns 4 and 5, and number of years of direct British rule in column 6. Data are missing for middle schools in Gujarat, high schools in Madhya Pradesh, and primary health subcenters in Karnataka. Data are missing for Assam in 1981 and Jammu and Kashmir in 1991.

reassure them against any future doctrines of lapse. This lends greater validity to our identifying assumption that the policy of lapse provides an exogenous determinant of British annexation, since the death of a ruler without a natural heir in the specific period 1848 to 1856 is likely to be a matter of circumstance rather than caused by systematic factors that might also affect long-term outcomes.

\section{Constructing an Instrumental Variable for Direct Colonial Rule}

For each native state, I construct an instrumental variable Lapse as follows: Lapse equals 1 if the native state was not annexed before 1848 and the ruler died without an heir in the period 1848 to 1856 ; Lapse equals 0 if the native state was not annexed before 1848 and such a death did not occur during the period 1848 to 1856 . Lapse cannot be assigned to places that were annexed before 1848, since these were already ruled by the British. Since the policy of lapse was irrelevant for places that were annexed before Lord Dalhousie came to India in 1848 , the sample for the IV regressions necessarily consists of places that had not been annexed in or before 1847 (hereafter referred to as the post-1847 sample). The sample thus consists of native states that were never annexed (Brit $=0$, Lapse $=0$ or 1), those that were annexed due to lapse after 1847 (Brit $=1$, Lapse $=1)$, and those that were annexed after 1847 by other means $($ Brit $=1$, Lapse $=0$ ). Using Lapse as an instrument for Brit would yield consistent estimates as long as Lapse itself does not have a

Table 5.-Deaths of Indian Rulers without Natural Heirs

\begin{tabular}{|c|c|c|c|c|c|c|c|}
\hline \multirow[b]{2}{*}{ Period } & \multirow[b]{2}{*}{ Governor-Generals } & \multicolumn{2}{|c|}{ Ruler Died without an Heir } & \multicolumn{2}{|c|}{ Annexed Due to Lapse } & \multicolumn{2}{|c|}{ Annexed Due to Other Reasons } \\
\hline & & $\begin{array}{c}\text { Number of } \\
\text { Native States }\end{array}$ & $\begin{array}{l}\text { Number of } \\
\text { Districts }\end{array}$ & $\begin{array}{l}\text { Number of } \\
\text { Native States }\end{array}$ & $\begin{array}{l}\text { Number of } \\
\text { Districts }\end{array}$ & $\begin{array}{l}\text { Number of } \\
\text { Native States }\end{array}$ & $\begin{array}{l}\text { Number of } \\
\text { Districts }\end{array}$ \\
\hline $1819-1827$ & Hastings, Amherst & 5 & 14 & 0 & 0 & 3 & 17 \\
\hline $1828-1835$ & Bentinck, Metcalfe & 6 & 9 & 0 & 0 & 2 & 4 \\
\hline $1836-1847$ & Auckland, Ellenborough, Hardinge & 15 & 31 & 1 & 1 & 4 & 19 \\
\hline 1848-1856 & Dalhousie & 8 & 20 & 4 & 16 & 3 & 18 \\
\hline $1857-1863$ & Canning, Elgin & 6 & 10 & 0 & 0 & 1 & 1 \\
\hline $1864-1875$ & Lawrence, Mayo, Northbrook & 7 & 20 & 0 & 0 & 0 & 0 \\
\hline $1876-1884$ & Lytton, Ripon & 3 & 5 & 0 & 0 & 0 & 0 \\
\hline
\end{tabular}




\begin{tabular}{|c|c|c|c|c|c|}
\hline \multicolumn{6}{|c|}{$\begin{array}{l}\text { TABle } 6 .- \text { First Stage of IV StRategy } \\
\text { DePENDENT VARIABle: BRITISH DumMY }\end{array}$} \\
\hline & \multicolumn{5}{|c|}{ Post-1847 Sample } \\
\hline & $\begin{array}{l}\text { No Controls } \\
\text { (1) }\end{array}$ & $\begin{array}{l}\text { Geography } \\
\text { (2) }\end{array}$ & $\begin{array}{l}\text { Soils } \\
(3)\end{array}$ & $\begin{array}{l}\text { Main Effects } \\
\text { (4) }\end{array}$ & $\begin{array}{l}\text { Exclude Punjab, Berar, Oudh } \\
(5)\end{array}$ \\
\hline $\begin{array}{l}\text { Ruler died without natural heir in 1848-1856 } \\
\text { (Instrument) }\end{array}$ & $\begin{array}{l}0.682 * * * \\
(0.159)\end{array}$ & $\begin{array}{l}0.673 * * * \\
(0.155)\end{array}$ & $\begin{array}{l}0.669 * * * \\
(0.162)\end{array}$ & $\begin{array}{l}0.953 * * * \\
(0.176)\end{array}$ & $\begin{array}{l}0.771 * * * \\
(0.140)\end{array}$ \\
\hline \multicolumn{6}{|l|}{ Main effects } \\
\hline Ruler died without heir & & & & $\begin{array}{c}-0.231 * \\
(0.126)\end{array}$ & $\begin{array}{c}0.027 \\
(0.121)\end{array}$ \\
\hline Ruler died in $1848-1856$ period & & & & $\begin{array}{r}-0.161 \\
(0.101)\end{array}$ & $\begin{array}{c}0.013 \\
(0.023)\end{array}$ \\
\hline \multicolumn{6}{|l|}{ Geography controls } \\
\hline Latitude & & $\begin{array}{c}0.012 \\
(0.011)\end{array}$ & $\begin{array}{c}0.016 \\
(0.011)\end{array}$ & $\begin{array}{c}0.015 \\
(0.012)\end{array}$ & $\begin{array}{c}-0.002 \\
(0.002)\end{array}$ \\
\hline Mean annual rainfall & & $\begin{array}{c}0.000 \\
(0.000)\end{array}$ & $\begin{array}{c}0.000 \\
(0.000)\end{array}$ & $\begin{array}{c}0.000 \\
(0.000)\end{array}$ & $\begin{array}{r}-0.000 \\
(0.000)\end{array}$ \\
\hline Coastal dummy & & $\begin{array}{r}-0.120 \\
(0.082)\end{array}$ & $\begin{array}{r}-0.096 \\
(0.100)\end{array}$ & $\begin{array}{r}-0.067 \\
(0.089)\end{array}$ & $\begin{array}{r}-0.016 \\
(0.024)\end{array}$ \\
\hline Proportion sandy & & $\begin{array}{c}-0.289 \\
(0.242)\end{array}$ & $\begin{array}{r}-0.119 \\
(0.241)\end{array}$ & $\begin{array}{c}-0.085 \\
(0.113)\end{array}$ & $\begin{array}{r}-0.033 \\
(0.061)\end{array}$ \\
\hline Proportion barren/rocky & & $\begin{array}{c}-2.791 \\
(1.773)\end{array}$ & $\begin{array}{c}-2.744 \\
(1.774)\end{array}$ & $\begin{array}{r}-2.188 \\
(1.839)\end{array}$ & $\begin{array}{c}-1.279 \\
(1.171)\end{array}$ \\
\hline Altitude $(\times 1 / 1000)$ & & & $\begin{array}{r}-0.000 \\
(0.000)\end{array}$ & & \\
\hline Black soil dummy & & & $\begin{array}{c}0.091 \\
(0.091)\end{array}$ & & \\
\hline Alluvial soil dummy & & & $\begin{array}{c}0.027 \\
(0.085)\end{array}$ & & \\
\hline Red soil dummy & & & $\begin{array}{r}-0.030 \\
(0.071)\end{array}$ & & \\
\hline Number of districts & 181 & 163 & 152 & 163 & 145 \\
\hline Number of native states & 73 & 71 & 67 & 71 & 68 \\
\hline$R^{2}$ & 0.29 & 0.35 & 0.37 & 0.42 & 0.73 \\
\hline
\end{tabular}

Note: Robust standard errors in parentheses, corrected for clustering within native states. * Significant at $10 \%$.

**** Significant at $1 \%$.

Post-1847 sample refers to areas that were not annexed in or before 1847. All results are from linear regressions. Main effect "Ruler died without heir" is a dummy that equals 1 if the native state had a ruler die without an heir at any time after 1818. Main effect "Ruler died in 1848-1856" is a dummy that equals 1 if the ruler of the native state died in the period 1848-1856.

direct impact on outcomes, even if there was some selectivity in British annexation among places with Lapse $=1 .^{17}$

The first-stage regression for the IV strategy is:

$$
\text { Brit }_{i}=\pi_{0}+\pi_{1} \text { Lapse }_{i}+\pi_{2} X_{i}+u_{i}
$$

where Lapse $_{i}$ is as defined above and $X_{i}$ are other control variables (mainly geography).

As expected from the historical description, the Lapse dummy is a statistically significant predictor of the Brit dummy, while geographic variables do not predict British annexation in the period after 1848 (table 6). Further, annexation is predicted by the interaction of two events: the ruler dying in the 1848-1856 period and the ruler dying without an heir and not by either of these separately (table 6, column 4). As expected, Lapse predicts British annexation even better if I drop the native states annexed for other reasons (table 6, column 5).

\section{Instrumental Variable Estimates}

As suggested by the comparison of late-annexed places with the native states, the instrumental variable estimates

\footnotetext{
${ }^{17}$ See Angrist and Krueger (1999) for a detailed explanation of this point.
}

show no significant advantages for directly ruled areas in terms of agricultural investments and productivity measures (table 7). All the IV estimates are smaller in magnitude than the OLS estimates and statistically insignificant (table 7, column 4). Further, the coefficients for fertilizer use, total yield, and rice yield are significantly different from the OLS estimates for the full sample. These results are robust to excluding the areas annexed by Lord Dalhousie for nonlapse reasons (table 7, column 5). The concern here is that these might be the "best" areas in some sense, since the British went to the trouble of annexing them even when the rulers did not die without natural heirs. ${ }^{18}$ The difference between the OLS and the IV results suggests a high degree of selectivity in British annexation policy, with annexation directed toward acquiring areas with the highest agricultural potential. This is not surprising in view of the fact that land revenue was the biggest source of government revenue throughout the colonial period. The mostly insignificant IV estimates in turn imply that British rule had no significant causal impact on long-term agricultural outcomes.

This lack of a causal effect on agricultural outcomes is not offset by directly ruled areas moving resources to other

\footnotetext{
${ }^{18}$ Note that since we have potentially removed the best places from the Lapse $=0$ group, these results are likely to be biased upward.
} 
Table 7.-Differences in Agricultural Investments and Productivity: IV Estimates

\begin{tabular}{|c|c|c|c|c|c|}
\hline & \multirow[b]{2}{*}{$\begin{array}{l}\text { Mean of Dependent } \\
\text { Variable } \\
\text { (1) }\end{array}$} & \multicolumn{4}{|c|}{ Coefficient } \\
\hline & & $\begin{array}{l}\text { British Dummy, } \\
\text { Full Sample } \\
\text { OLS } \\
\text { (2) }\end{array}$ & $\begin{array}{l}\text { British Dummy, } \\
\text { Post-1847 Sample } \\
\text { OLS } \\
\text { (3) }\end{array}$ & $\begin{array}{l}\text { British Dummy, } \\
\text { Post-1847 Sample } \\
\text { IV } \\
\text { (4) }\end{array}$ & $\begin{array}{c}\text { British Dummy, Post-1847 Sample } \\
\text { (excluding Punjab, Oudh, Berar) } \\
\text { IV } \\
\text { (5) }\end{array}$ \\
\hline \multicolumn{6}{|c|}{ Dependent variables (1956-1987 mean) } \\
\hline Proportion of area irrigated & 0.228 & $\begin{array}{l}0.099 * * * \\
(0.037)\end{array}$ & $\begin{array}{c}0.063 \\
(0.046)\end{array}$ & $\begin{array}{c}0.059 \\
(0.065)\end{array}$ & $\begin{array}{c}0.058 \\
(0.053)\end{array}$ \\
\hline Fertilizer usage (kg/hectare) & 20.04 & $\begin{array}{l}7.014 * * \\
(3.073)\end{array}$ & $\begin{array}{l}3.770 \\
(4.251)\end{array}$ & $\begin{array}{l}-3.145 \\
(3.765)\end{array}$ & $\begin{array}{r}-2.054 \\
(2.669)\end{array}$ \\
\hline $\begin{array}{c}\text { Proportion of cereal area sown } \\
\text { with high-yielding varieties }\end{array}$ & 0.330 & $\begin{array}{l}0.066^{* * *} \\
(0.028)\end{array}$ & $\begin{array}{l}0.083 * * \\
(0.037)\end{array}$ & $\begin{array}{c}0.051 \\
(0.038)\end{array}$ & $\begin{array}{c}0.061 * \\
(0.033)\end{array}$ \\
\hline $\begin{array}{l}\text { Log total yield ( } 15 \text { major } \\
\text { crops) }\end{array}$ & -0.161 & $\begin{array}{l}0.213^{* * *} \\
(0.080)\end{array}$ & $\begin{array}{c}0.117 \\
(0.119)\end{array}$ & $\begin{array}{c}0.087 \\
(0.127)\end{array}$ & $\begin{array}{c}0.082 \\
(0.105)\end{array}$ \\
\hline Log rice yield & -0.077 & $\begin{array}{c}0.151^{*} \\
(0.083)\end{array}$ & $\begin{array}{c}0.046 \\
(0.120)\end{array}$ & $\begin{array}{r}-0.107 \\
(0.215)\end{array}$ & $\begin{array}{r}-0.090 \\
(0.166)\end{array}$ \\
\hline Log wheat yield & -0.114 & $\begin{array}{c}-0.064 \\
(0.088)\end{array}$ & $\begin{array}{r}-0.089 \\
(0.113)\end{array}$ & $\begin{array}{r}-0.184 \\
(0.243)\end{array}$ & $\begin{array}{r}-0.164 \\
(0.219)\end{array}$ \\
\hline \multicolumn{6}{|l|}{ Controls } \\
\hline Latitude, rainfall, coast & & Yes & Yes & Yes & Yes \\
\hline Proportion sandy/barren & & Yes & Yes & Yes & Yes \\
\hline Soil type dummies & & Yes & Yes & Yes & Yes \\
\hline Number of districts & & 271 & 136 & 136 & 118 \\
\hline Number of native states & & 83 & 58 & 58 & 55 \\
\hline
\end{tabular}

sectors. For instance, the directly ruled areas have a similar proportion of their workforce employed in manufacturing compared to indirectly ruled areas over the period 1961 to 1991. IV results for 1991 alone indicate that indirectly ruled areas in fact have a slightly higher proportion of their workforce in manufacturing (table A.1).

Turning to the availability of health and education infrastructure, the IV estimates indicate a statistically significant negative impact of direct British rule on the availability of middle schools, health centers, and roads (table 8, column 4). The IV estimates imply very large differences in public goods availability: districts that were part of the British Empire have 37\% fewer villages with middle schools, $70 \%$ fewer villages equipped with primary health subcenters, and $46 \%$ fewer villages with access to good roads in 1981 and 1991.

These differences in access to health and education facilities have implications for development outcomes. The IV estimates show that infant mortality rates were significantly higher in British areas (table 9). We see no significant differences in literacy rates, which probably reflects the fact that the differences in primary schools are no longer significant in the 1981 and 1991 data. In terms of overall welfare, we find that areas under direct rule have significantly higher proportions of their population below the poverty line over the period 1983 to 1993 . These differences are very large in magnitude: directly ruled British areas have nearly $40 \%$ higher poverty rates and 33\% higher infant mortality rates in the early 1990s compared to native state areas. These gains are also more widespread in the sense that native state areas have lower levels of consumption inequality during these periods.

I perform a number of specification checks for the IV results before discussing the validity of this instrumental variable strategy. The IV estimates are robust to dropping the areas annexed by Lord Dalhousie for nonlapse reasons (table 8, column 6), to the addition of soil type dummies (the overall estimate for the combined public goods regression is -0.062), and to controlling for population density (overall public goods difference is now -0.057 ), though population density is probably endogenous in this context, since it has the potential of being affected by public health policies. ${ }^{19}$ The results are also robust to dropping the native states of Mysore and Travancore, which were arguably the best in terms of public goods provision. The religion of the ruler has some impact: areas ruled by Sikh kings were much more likely to have better postcolonial outcomes, while there are few significant differences between the areas ruled by Hindu or Muslim kings (table A.2).

\section{Assessing the Validity of Lapse as an Instrument}

The validity of the identification strategy rests on the assumption that Lapse is a legitimate instrument for British rule. This means that Lapse must be uncorrelated with the residual error term $\epsilon$ in equation (1). In other words, if the event of ruler death without a natural heir in the period 1848

\footnotetext{
${ }^{19}$ This was especially true in the colonial period when the major cause of death was from epidemics and famines.
} 
Table 8.-Differences in Public Goods Levels: IV Estimates

\begin{tabular}{|c|c|c|c|c|c|}
\hline & \multirow[b]{2}{*}{$\begin{array}{c}\text { Mean of Dependent } \\
\text { Variable } \\
\text { (1) }\end{array}$} & \multicolumn{4}{|c|}{ Coefficient } \\
\hline & & $\begin{array}{l}\text { British Dummy, } \\
\text { Full Sample } \\
\text { OLS } \\
\text { (2) }\end{array}$ & $\begin{array}{c}\text { British Dummy, } \\
\text { Post-1847 Sample } \\
\text { OLS } \\
\text { (3) }\end{array}$ & $\begin{array}{l}\text { British Dummy, } \\
\text { Post-1847 Sample } \\
\text { IV } \\
\text { (4) }\end{array}$ & $\begin{array}{c}\text { British Dummy, Post-1847 Sample } \\
\text { (excluding Punjab, Oudh, Berar) } \\
\text { IV } \\
\text { (5) }\end{array}$ \\
\hline \multicolumn{6}{|c|}{ Dependent variables: Proportion of villages having public goods (mean of 1981 and 1991 data) } \\
\hline Primary school & 0.7720 & $\begin{array}{r}-0.016 \\
(0.032)\end{array}$ & $\begin{array}{r}-0.007 \\
(0.039)\end{array}$ & $\begin{array}{c}-0.011 \\
(0.041)\end{array}$ & $\begin{array}{c}-0.012 \\
(0.036)\end{array}$ \\
\hline Middle school & 0.2485 & $\begin{array}{r}-0.046 \\
(0.034)\end{array}$ & $\begin{array}{r}-0.047 \\
(0.031)\end{array}$ & $\begin{array}{c}-0.091 * * \\
(0.037)\end{array}$ & $\begin{array}{c}-0.083^{* *} \\
(0.032)\end{array}$ \\
\hline High school & 0.1260 & $\begin{array}{r}-0.068 * \\
(0.040)\end{array}$ & $\begin{array}{c}-0.061 * \\
(0.033)\end{array}$ & $\begin{array}{c}-0.065 \\
(0.042)\end{array}$ & $\begin{array}{c}-0.064 * \\
(0.037)\end{array}$ \\
\hline Primary health center & 0.0415 & $\begin{array}{r}-0.024 * \\
(0.014)\end{array}$ & $\begin{array}{c}-0.015^{*} \\
(0.008)\end{array}$ & $\begin{array}{c}-0.031 * * \\
(0.013)\end{array}$ & $\begin{array}{c}-0.028^{* *} \\
(0.011)\end{array}$ \\
\hline Primary health subcenter & 0.0753 & $\begin{array}{c}-0.002 \\
(0.017)\end{array}$ & $\begin{array}{r}-0.007 \\
(0.017)\end{array}$ & $\begin{array}{c}-0.053 * * \\
(0.021)\end{array}$ & $\begin{array}{c}-0.043^{* * *} * \\
(0.016)\end{array}$ \\
\hline Canals & 0.0477 & $\begin{array}{r}-0.010 \\
(0.014)\end{array}$ & $\begin{array}{r}-0.024^{*} \\
(0.014)\end{array}$ & $\begin{array}{c}-0.043 \\
(0.028)\end{array}$ & $\begin{array}{c}-0.041^{*} \\
(0.024)\end{array}$ \\
\hline Roads & 0.4344 & $\begin{array}{c}0.043 \\
(0.065)\end{array}$ & $\begin{array}{r}-0.010 \\
(0.067)\end{array}$ & $\begin{array}{c}-0.198 * * * \\
(0.066)\end{array}$ & $\begin{array}{c}-0.157 * * * \\
(0.050)\end{array}$ \\
\hline Combined public goods & 0.2535 & $\begin{array}{r}-0.017 \\
(0.025)\end{array}$ & $\begin{array}{r}-0.026 \\
(0.021)\end{array}$ & $\begin{array}{c}-0.075^{* * * *} \\
(0.023)\end{array}$ & $\begin{array}{c}-0.065^{* * * *} \\
(0.019)\end{array}$ \\
\hline \multicolumn{6}{|l|}{ Controls } \\
\hline Latitude, rainfall, coast & & Yes & Yes & Yes & Yes \\
\hline Proportion of sandy/barren & & Yes & Yes & Yes & Yes \\
\hline Number of districts & & 377 & 163 & 163 & 145 \\
\hline Number of native states & & 96 & 71 & 71 & 68 \\
\hline
\end{tabular}

Note: Robust standard errors in parentheses, corrected for clustering within native states.

* Significant at $10 \%$.

**Significant at $5 \%$.

IV estimate computed using the Lapse dummy as an instrument for British rule. Lapse $=1$ if ruler died without a natural heir in the period 1848-1856. Post-1847 sample refers to areas that were not annexed in or before 1847. Data are missing for middle schools in Gujarat, high schools in Madhya Pradesh, and primary health subcenters in Karnataka. Data are missing for Assam in 1981 and Jammu and Kashmir in 1991.

to 1856 influences long-term outcomes for reasons other than British annexation, or if the areas with Lapse $=1$ are in some way different from other areas, then the instrumental variable estimates are no longer consistent. In this section, I consider various arguments that might affect the validity of my instrument. Some of these arguments are countered by the historical evidence and some by direct econometric tests. I run most of these tests on the reducedform specification, the results of which are very similar to the IV specification (table 10 , column 1 ). ${ }^{20}$

First, Lapse may not be a valid instrument if the policy was tailored toward acquiring native states with certain characteristics. The historical evidence does not support the case that the Doctrine of Lapse was put in place in order to obtain any specific states. In particular, Lord Dalhousie admitted that the states he most wanted were Oudh and Hyderabad; ${ }^{21}$ however, neither of these could be annexed by lapse, since the rulers of both states already had natural heirs when Dalhousie arrived in India. They were in fact annexed by other means. ${ }^{22}$ The Doctrine of Lapse thus seems to have

${ }^{20}$ Since we have a case of one endogenous variable and one instrument, the IV coefficients are exactly equal to the reduced-form coefficients divided by the coefficient on the instrument in the first stage.

21 "I have got two other kingdoms on hand to dispose of-Oudh and Hyderabad. Both are on the highroad to be taken under our management." Private correspondence of Lord Dalhousie in 1848, quoted in Rahim (1963).

22 The ruler of Oudh was accused of misrule, and part of Hyderabad was annexed due to nonpayment of debts.
Table 9.-Health and Education Outcomes

\begin{tabular}{|c|c|c|c|}
\hline \multirow[b]{2}{*}{ Dependent Variables } & \multirow[b]{2}{*}{ Mean } & \multicolumn{2}{|c|}{ Coefficient } \\
\hline & & $\begin{array}{c}\text { British Dummy, } \\
\text { Full Sample } \\
\text { OLS }\end{array}$ & $\begin{array}{c}\text { British Dummy, } \\
\text { Post-1847 Sample } \\
\text { IV }\end{array}$ \\
\hline $\begin{array}{l}\text { Literacy rate }(1961,1971, \\
\quad 1981,1991)\end{array}$ & 0.309 & $\begin{array}{c}0.017 \\
(0.022)\end{array}$ & $\begin{array}{c}0.019 \\
(0.042)\end{array}$ \\
\hline Infant mortality rate 1981 & 118.7 & $\begin{array}{c}-0.481 \\
(7.48)\end{array}$ & $\begin{array}{l}37.35 * * \\
(14.20)\end{array}$ \\
\hline Infant mortality rate 1991 & 80.04 & $\begin{array}{c}-0.772 \\
(6.36)\end{array}$ & $\begin{array}{l}26.87 * * \\
(10.54)\end{array}$ \\
\hline Poverty 1983 & 0.436 & $\begin{array}{l}0.093 * * \\
(0.037)\end{array}$ & $\begin{array}{l}0.223 * * \\
(0.097)\end{array}$ \\
\hline Poverty 1987 & 0.375 & $\begin{array}{c}0.048 \\
(0.042)\end{array}$ & $\begin{array}{l}0.139 * * \\
(0.064)\end{array}$ \\
\hline Poverty 1993 & 0.315 & $\begin{array}{c}0.066^{*} \\
(0.034)\end{array}$ & $\begin{array}{l}0.123 * * * \\
(0.044)\end{array}$ \\
\hline Inequality 1983 & 0.500 & $\begin{array}{c}-0.021^{*} \\
(0.011)\end{array}$ & $\begin{array}{c}-0.064 * * * \\
(0.014)\end{array}$ \\
\hline Inequality 1987 & 0.460 & $\begin{array}{r}-0.011 \\
(0.013)\end{array}$ & $\begin{array}{r}-0.045^{*} \\
(0.023)\end{array}$ \\
\hline Inequality 1993 & 0.428 & $\begin{array}{c}0.002 \\
(0.018)\end{array}$ & $\begin{array}{l}-0.079 * * \\
(0.032)\end{array}$ \\
\hline \multicolumn{4}{|l|}{ Controls } \\
\hline Latitude, rainfall, coast & & Yes & Yes \\
\hline Proportion sandy/barren & & Yes & Yes \\
\hline Number of districts & & 377 & 157 \\
\hline Number of native states & & 96 & 69 \\
\hline \multicolumn{4}{|c|}{$\begin{array}{l}\text { Note: Robust standard errors in parentheses, corrected for clustering within native states. } \\
* \text { Significant at } 10 \% \text {. } \\
\text { **Significant at } 5 \% \text {. } \\
\text { ***Significant at } 1 \% \text {. } \\
\text { Post- } 1847 \text { sample refers to areas that were not annexed in or before } 1847 \text {. Instrument is a dummy for } \\
\text { whether the ruler died without an heir in the period } 1848-1856 \text {. Infant mortality rate is computed as the } \\
\text { number of deaths per } 1,000 \text { live births. The measure of poverty is the head count ratio, which measures } \\
\text { the proportion of people below the poverty line in a district. The measure of inequality is the standard } \\
\text { deviation of log consumption. The number of observations for the poverty and inequality regressions is } \\
360 \text { for the OLS regressions and } 160 \text { for the IV regressions. }\end{array}$} \\
\hline
\end{tabular}


Table 10.-Reduced-Form Regressions for Public Goods: Robustness Checks

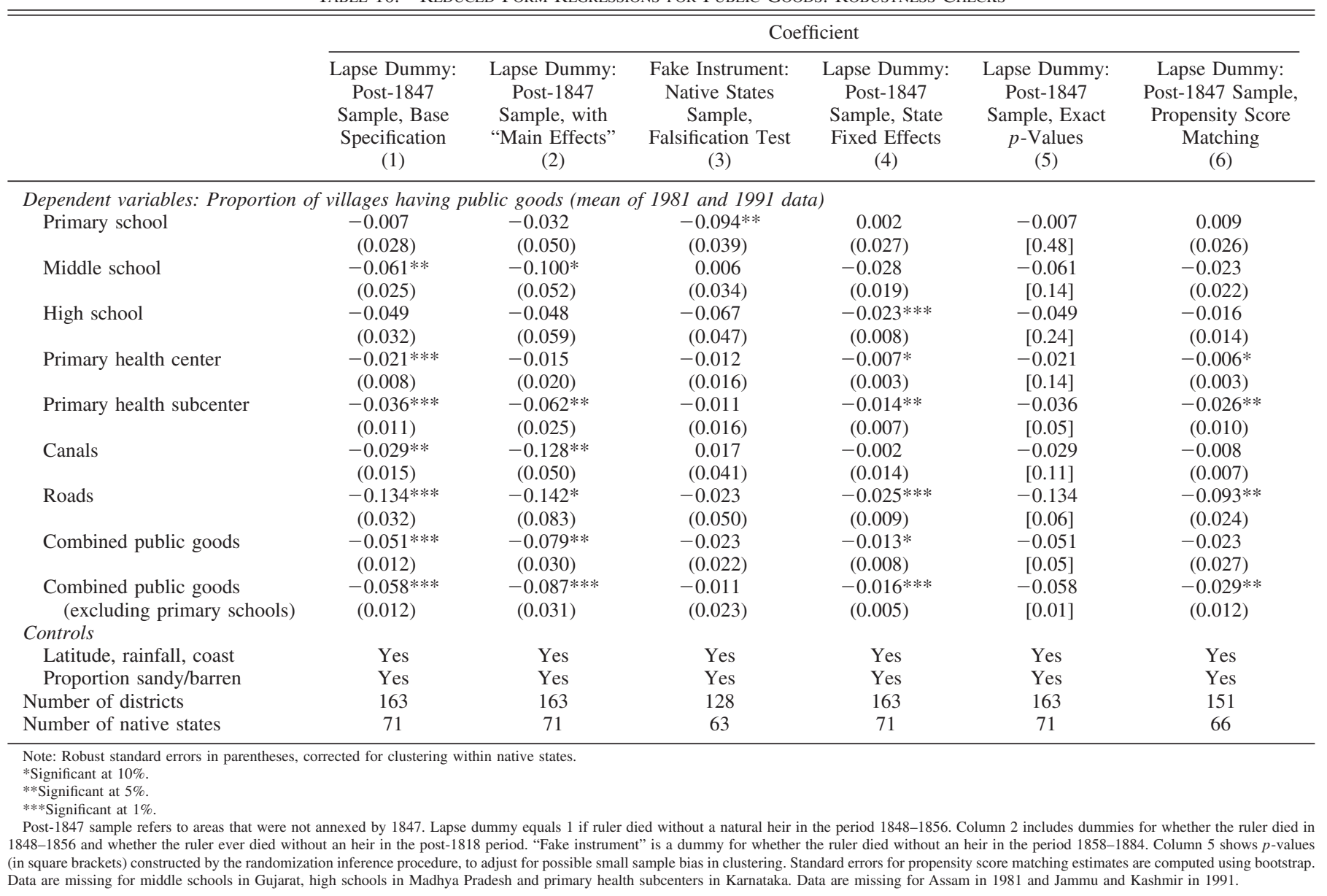

been an additional means to annex more territory and was not targeted to any particular state.

Second, the instrument may be called into question if the British deliberately caused the death of certain rulers. Again, the historical evidence does not indicate any such moves on their part, and they were never accused of this even by the royal families affected by the Doctrine of Lapse. A related issue is the question of whether some native states established take natural heirs to avoid being taken over by lapse. The unexpected nature of Dalhousie's policy and the prominence of royal families suggest that this was not very easy to do; there are also no accounts of the British being suspicious of the bona fides of natural heirs.

Third, it is possible that the event of a ruler dying without an heir might reflect some characteristics of the area (such as bad climate) or of the ruling family (such as genetic weaknesses), which might arguably affect long-term outcomes directly. To control for this, I reran the regressions of public goods on the Lapse dummy after adding dummies for ruler death in the 1848 to 1856 period (as a proxy for poor conditions in those years) and for the ruler ever dying without heirs in the post-1818 period (as a proxy for a physically weak royal family). The estimates obtained are in fact larger in magnitude than the specification without these controls (table 10, column 2). Further, these controls are usually insignificant in all the regressions.

Fourth, I checked directly whether ruler death without natural heirs has any long-term impact on public goods availability without British annexation. For instance, such a death may result in an extended period of political turmoil, which might have lasting consequences. As mentioned earlier, the policy of lapse was officially given up after 1858. I regress public goods outcomes on a dummy that equals 1 if the ruler died without a natural heir in the period 1858 to 1884 during which such a death would not result in British annexation. ${ }^{23}$ The estimates using this "fake instrument" are much lower in magnitude than the results using the Lapse dummy, and they are also statistically insignificant (table 10, column 3). This falsification test strongly supports the hypothesis that the impact of Lapse is only through British annexation.

Fifth, it was not the case that territories annexed by lapse were administered differently compared to areas annexed by other means. The lapsed areas were added to existing British provinces and brought under the prevailing administrative

\footnotetext{
${ }^{23}$ There were twelve such deaths in ten native states of our data set.
} 
TABle 11.-Differences in Public Goods LeVEls IN 1961 AND 1911

\begin{tabular}{|c|c|c|c|c|c|}
\hline & \multirow[b]{2}{*}{$\begin{array}{c}\text { Mean of Dependent } \\
\text { Variable }\end{array}$} & \multirow[b]{2}{*}{$\begin{array}{l}\text { Number of Districts } \\
\text { (Number of Native } \\
\text { States) }\end{array}$} & \multicolumn{3}{|c|}{ Coefficient } \\
\hline & & & $\begin{array}{l}\text { British Dummy, } \\
\text { OLS: } \\
\text { Full Sample }\end{array}$ & $\begin{array}{l}\text { British Dummy, } \\
\text { IV: } \\
\text { Post-1847 Sample }\end{array}$ & $\begin{array}{c}\text { British Dummy, IV: } \\
\text { Post-1847 Sample } \\
\text { (excluding Punjab, Oudh, Berar) }\end{array}$ \\
\hline \multicolumn{6}{|c|}{ A: Proportion of villages having public goods in 1961} \\
\hline Primary school & 0.5126 & $234(81)$ & $\begin{array}{c}0.024 \\
(0.041)\end{array}$ & $\begin{array}{r}-0.127 * \\
(0.067)\end{array}$ & $\begin{array}{c}-0.106 * \\
(0.062)\end{array}$ \\
\hline Middle school & 0.0972 & $219(78)$ & $\begin{array}{r}-0.040 \\
(0.035)\end{array}$ & $\begin{array}{c}-0.068^{*} \\
(0.035)\end{array}$ & $\begin{array}{r}-0.058^{*} \\
(0.030)\end{array}$ \\
\hline High school & 0.0303 & $286(88)$ & $\begin{array}{r}-0.032 \\
(0.020)\end{array}$ & $\begin{array}{r}-0.037 \\
(0.022)\end{array}$ & $\begin{array}{c}-0.031^{*} \\
(0.018)\end{array}$ \\
\hline Dispensaries & 0.0733 & $234(81)$ & $\begin{array}{c}-0.075^{*} \\
(0.043)\end{array}$ & $\begin{array}{c}-0.069^{*} \\
(0.039)\end{array}$ & $\begin{array}{c}-0.062^{*} \\
(0.036)\end{array}$ \\
\hline Rural health center & 0.0244 & $159(54)$ & $\begin{array}{r}-0.007 \\
(0.010)\end{array}$ & $\begin{array}{c}-0.007 \\
(0.008)\end{array}$ & $\begin{array}{c}-0.005 \\
(0.007)\end{array}$ \\
\hline Canals & 0.0017 & $134(49)$ & $\begin{array}{c}0.003 \\
(0.003)\end{array}$ & $\begin{array}{r}-0.000 \\
(0.000)\end{array}$ & $\begin{array}{r}-0.000 \\
(0.000)\end{array}$ \\
\hline Roads & 0.2124 & $234(68)$ & $\begin{array}{c}0.052 \\
(0.055)\end{array}$ & $\begin{array}{r}-0.077 \\
(0.092)\end{array}$ & $\begin{array}{r}-0.047 \\
(0.069)\end{array}$ \\
\hline \multicolumn{6}{|l|}{ B: 1911 census } \\
\hline Fraction literate & 0.052 & $311(121)$ & $\begin{array}{c}0.006 \\
(0.009)\end{array}$ & $\begin{array}{c}-0.035^{*} \\
(0.018)\end{array}$ & $\begin{array}{l}-0.029 * * \\
(0.014)\end{array}$ \\
\hline \multicolumn{6}{|l|}{ Controls } \\
\hline Latitude, rainfall, coast & & & Yes & Yes & Yes \\
\hline Proportion sandy/barren & & & Yes & Yes & Yes \\
\hline
\end{tabular}

Note: Robust standard errors in parentheses, corrected for clustering within native states.

* Significant at $10 \%$.

**Significant at $5 \%$.

Post-1847 sample refers to areas that were not annexed in or before 1847. Instrument is a dummy for whether the ruler died without an heir in the period 1848-1856. Data on rural health centers and canals are missing for UP, Tamil Nadu, Rajasthan, Orissa, and Maharashtra. Data on primary schools, middle schools, and dispensaries are missing for Uttar Pradesh. Data on middle schools, canals, and roads are missing for West Bengal. Data on roads are missing for Punjab and Rajasthan. Regressions for 1911 literacy data are at the level of the native state for smaller native states and at the district level for larger native states and British areas. Regressions include controls for total population and sex ratio.

systems in those provinces. In particular, we should note that they were integrated into different British provinces: Nagpur and Sambalpur were merged with the Central Provinces, Satara with Bombay, and Jhansi with the North-West Provinces. In the postcolonial period as well, these areas belong to four different states. I explicitly include state fixed effects to see whether state-level policies can explain the differences between areas under direct and indirect rule. We see that many of the public goods differences continue to be significant, though they are lower in magnitude (table 10, column 4). Thus, the results we observe cannot be fully attributed to a specific administrative difference or state policy.

Sixth, the standard errors might be incorrect due to a small sample bias. I correct for possible correlation of errors within districts of the same native states by using the method of clustering, but the consistency of these standard errors requires a large sample. To account for this, I compute exact finite-sample $p$-values for the estimates using the method of randomization inference. ${ }^{24}$ This consists of reassigning the Lapse dummy randomly, computing the reducedform estimator, and simulating the finite sample distribution of our estimator. The implied standard errors are larger than the ones obtained by clustering, but our overall estimate is still significant, with a $p$-value of 0.05 (table 10, column 5).

Finally, I present propensity score matching estimates for the reduced-form regressions. The small size of the data set does not make it particularly well suited for propensity

\footnotetext{
${ }^{24}$ See Bertrand, Duflo, and Mullainathan (2004) for details.
}

score matching methods. ${ }^{25}$ Nevertheless, the balancing property was satisfied, and several of the propensity score matching estimates are still statistically significant, though the magnitudes are smaller than the baseline estimates (table 10 , column 6). It is also worth pointing out that the coefficient for the combined public goods becomes larger $(-0.034)$ when we do not include primary schools and also becomes statistically significant.

These robustness checks support the conclusion that direct British rule had a significant negative impact on the availability of public goods in the postcolonial period.

\section{Differences in Outcomes in Earlier Periods}

The differences in human capital investments I have documented were present in the colonial period and are narrowing over time in the postcolonial period, when British areas and native states were subjected to a uniform system of administration. I provide three pieces of evidence toward this view. First, IV estimates using public goods data from 1961 show that British Empire areas had lower levels of primary schools, middle schools, and medical dispensaries in 1961, though as before, the OLS results do not indicate any significant differences (table 11). ${ }^{26}$ Though the estimated differences for middle and high schools are lower in

\footnotetext{
25 See Zhao (2004) for some evidence that propensity score matching does not work as well as other methods when the sample size is small.

26 The data on rural health centers, canals, and roads are missing for several states in this year.
} 
magnitude than the differences in table 10, they are larger as a proportion of the mean level in 1961. It is also interesting to note large differences in the availability of primary schools, which are not present in the later period data.

Second, controlling explicitly for the 1961 level reduces the magnitude and statistical significance of the results from 1981 to 1991 (table A.3), though some of the IV coefficients are still significant at the $10 \%$ level of significance. We note a similar trend in the infant mortality and poverty results in table 9: the difference in the later periods is smaller (in percentage terms) than in the earlier period. This is consistent with the strong convergence effects on public goods provision documented in Banerjee and Somanathan (2007), mainly due to the explicit commitments by the Indian government to equalize access to public goods. On the other hand, there does not seem to be any noticeable time path in the agricultural outcomes: the OLS and IV results for 1956 (the first year for which I have data) are not statistically difference from the overall results, except for fertilizer use where the difference is insignificant in the early periods but becomes larger in the later periods (regressions not shown).

Overall, these results strongly suggest that postcolonial institutions did not contribute to the differences in outcomes across areas with direct and indirect rule and may in fact have mitigated some of these differences. I also test this directly by examining whether one specific postcolonial institution, electoral democracy, worked differently across areas of direct and indirect rule. As detailed in section III, this is an institution that might function differently across these two types of areas. Using data on state-level elections from the 1960s and from the 1980s, I find that there are no significant differences in voter turnout or the vote margin of the winning candidates, a proxy for the competitiveness of elections (table A.4).

Third, I use literacy data from the 1911 census to provide direct evidence of human capital differences in the colonial period. Though the overall level of literacy was very low during this period (only $5.2 \%$ of the population could read and write), the literacy rate in British areas was 3 percentage points lower (table 11, panel B). This is in contrast to the lack of any literacy difference in the postcolonial period (table 9), which is consistent with the differences in the availability of primary schools being wiped out by postcolonial policy.

Historical descriptions also indicate that at least some native states were greatly committed to investments in education and health during the colonial period. For instance, the native state of Mysore carried out smallpox vaccination as early as 1806. The state of Travancore announced a policy of free primary education in 1817, whereas the East India Company decided to give assistance "to the more extended and systematic promotion of general education in India" only after the influential dispatch written by Sir Charles Wood in 1854. The state of Baroda was probably the first to introduce compulsory primary educa- tion in 1892, while the British passed a compulsory education act in the nearby Central Provinces only in 1920. Roy (2000) also notes that "the British government did not build an effective mass education system."

\section{Why Did the Native States Provide More Public Goods?}

In this section, I examine specific institutional differences across areas with direct and indirect rule in the colonial period, as discussed in section III. I first verify that the differences in public goods are not explained by differences in the level of taxes collected by the native states. We should note that native states raised more revenues from their subjects than the British did: revenue figures from the 1890s indicate that the native states raised 3.42 rupees per capita in revenue, while the corresponding figure for British India was only 2.47 rupees. ${ }^{27} \mathrm{I}$ reran the IV regression and added a control variable for taxes collected per capita in 1896 . The coefficient on the dummy for direct British rule remains almost unchanged, while the tax variable is never statistically significant (table 12, column 2).

The second institution I examine is the type of land revenue system. We find that native states are not more likely to have a different land revenue system on average: $63 \%$ of native state districts are classified as having cultivatorbased systems compared to $62 \%$ of British districts. Controlling for this important historical institution reduces the magnitude of the differences on the direct rule dummy, but the overall difference remains significant at the $10 \%$ level of significance, and the land revenue system variable itself is rarely statistically significant (table 12 , column 3 ). I investigate this relationship further by looking at the impact of land revenue systems separately within British and native state areas. I find that a cultivator-based land revenue system is associated with better public goods outcomes within British areas, consistent with the results of Banerjee and Iyer (2005), but that the land revenue system does not matter within native state areas (table A.5, columns 1 and 2). ${ }^{28}$ Taken together with the overall negative effects of direct rule, these results suggest that having a more equitable land revenue system can mitigate the effects of direct colonial rule. If we think of having an intermediary landlord class as another way of instituting indirect rule, the key

\footnotetext{
${ }^{27}$ The revenue and tribute data were obtained from Chakrabarti (1896). Native states paid tribute to the British out of their revenues; subtracting this from their collections and adding the tribute amount to the British revenues means that native states had 3.20 rupees per capita available for spending, while the British areas had 2.69 rupees.

${ }^{28}$ I thank an anonymous referee for this suggestion. I also tried combining these two regressions by adding the interaction of the direct rule dummy and the cultivator-based land revenue system dummy as an additional variable. I find that the difference between the direct and indirectly ruled areas is mainly for areas with a landlord-based land revenue system. Among places with a cultivator-based land revenue system, the difference between direct and indirect rule areas is statistically insignificant.
} 
Table 12.-The Role of Tax Revenues, Institutions, and Ruler Quality in Public Goods Provision

\begin{tabular}{|c|c|c|c|c|c|c|c|}
\hline & \multirow{3}{*}{$\begin{array}{c}\text { Base } \\
\text { Specification } \\
\text { British Dummy } \\
\text { IV }\end{array}$} & \multicolumn{2}{|c|}{$\begin{array}{l}\text { Controlling for Tax Revenue } \\
\text { per Capita }\end{array}$} & \multicolumn{2}{|c|}{$\begin{array}{l}\text { Controlling for Land Tenure } \\
\text { System }\end{array}$} & \multicolumn{2}{|c|}{$\begin{array}{l}\text { Controlling for Whether } \\
\text { Ruler Was Ever Deposed by }\end{array}$} \\
\hline & & British Dummy & $\begin{array}{l}\text { Tax Revenue } \\
\text { per Capita }\end{array}$ & British Dummy & $\begin{array}{l}\text { Cultivator-Based } \\
\text { Land Revenue } \\
\text { System Dummy }\end{array}$ & British Dummy & $\begin{array}{l}\text { Ruler Ever } \\
\text { Deposed }\end{array}$ \\
\hline & & \multicolumn{2}{|c|}{ IV } & \multicolumn{2}{|c|}{ IV } & \multicolumn{2}{|l|}{ IV } \\
\hline & (1) & \multicolumn{2}{|c|}{ (2) } & \multicolumn{2}{|c|}{ (3) } & \multicolumn{2}{|c|}{ (4) } \\
\hline \multicolumn{8}{|c|}{ Dependent variables: Proportion of villages having public goods (mean of 1981 and 1991 data) } \\
\hline Primary school & $\begin{array}{c}-0.011 \\
(0.041)\end{array}$ & $\begin{array}{c}0.012 \\
(0.046)\end{array}$ & $\begin{array}{c}0.014 \\
(0.011)\end{array}$ & $\begin{array}{c}0.064 \\
(0.046)\end{array}$ & $\begin{array}{l}0.090 * * \\
(0.044)\end{array}$ & $\begin{array}{c}-0.019 \\
(0.045)\end{array}$ & $\begin{array}{c}-0.045 \\
(0.044)\end{array}$ \\
\hline Middle school & $\begin{array}{c}-0.091 * * \\
(0.037)\end{array}$ & $\begin{array}{c}-0.049 \\
(0.034)\end{array}$ & $\begin{array}{c}0.000 \\
(0.007)\end{array}$ & $\begin{array}{r}-0.063 \\
(0.051)\end{array}$ & $\begin{array}{l}0.035 \\
(0.036)\end{array}$ & $\begin{array}{c}-0.103 * * \\
(0.039)\end{array}$ & $\begin{array}{c}-0.074 * * \\
(0.031)\end{array}$ \\
\hline High school & $\begin{array}{c}-0.065 \\
(0.042)\end{array}$ & $\begin{array}{l}-0.102 * * \\
(0.049)\end{array}$ & $\begin{array}{c}-0.005 \\
(0.008)\end{array}$ & $\begin{array}{c}-0.065 \\
(0.054)\end{array}$ & $\begin{array}{c}0.006 \\
(0.037)\end{array}$ & $\begin{array}{c}-0.070 \\
(0.049)\end{array}$ & $\begin{array}{c}-0.027 \\
(0.048)\end{array}$ \\
\hline Primary health center & $\begin{array}{l}-0.031 * * \\
(0.013)\end{array}$ & $\begin{array}{c}-0.063^{*} \\
(0.036)\end{array}$ & $\begin{array}{c}0.001 \\
(0.010)\end{array}$ & $\begin{array}{l}-0.034 * * \\
(0.016)\end{array}$ & $\begin{array}{r}-0.005 \\
(0.010)\end{array}$ & $\begin{array}{c}-0.035^{* *} \\
(0.015)\end{array}$ & $\begin{array}{r}-0.020 \\
(0.014)\end{array}$ \\
\hline $\begin{array}{l}\text { Primary health } \\
\text { subcenter }\end{array}$ & $\begin{array}{c}-0.053^{* * *} \\
(0.021)\end{array}$ & $\begin{array}{r}-0.066 \\
(0.055)\end{array}$ & $\begin{array}{c}0.001 \\
(0.013)\end{array}$ & $\begin{array}{c}-0.050^{*} \\
(0.027)\end{array}$ & $\begin{array}{l}0.001 \\
(0.019)\end{array}$ & $\begin{array}{l}-0.061 * * * \\
(0.021)\end{array}$ & $\begin{array}{r}-0.039^{*} \\
(0.023)\end{array}$ \\
\hline Canals & $\begin{array}{c}-0.043 \\
(0.028)\end{array}$ & $\begin{array}{l}-0.034 * * \\
(0.017)\end{array}$ & $\begin{array}{c}-0.001 \\
(0.003)\end{array}$ & $\begin{array}{c}-0.031 \\
(0.022)\end{array}$ & $\begin{array}{r}-0.002 \\
(0.019)\end{array}$ & $\begin{array}{c}-0.048 \\
(0.029)\end{array}$ & $\begin{array}{r}-0.028 \\
(0.019)\end{array}$ \\
\hline Roads & $\begin{array}{l}-0.198 * * * \\
(0.066)\end{array}$ & $\begin{array}{l}-0.230 * * * \\
(0.086)\end{array}$ & $\begin{array}{r}-0.013 \\
(0.015)\end{array}$ & $\begin{array}{c}-0.163^{*} \\
(0.093)\end{array}$ & $\begin{array}{c}0.113 \\
(0.089)\end{array}$ & $\begin{array}{l}-0.225 * * * \\
(0.069)\end{array}$ & $\begin{array}{l}-0.151 * * \\
(0.073)\end{array}$ \\
\hline Combined public goods & $\begin{array}{l}-0.075^{* * * *} \\
(0.023)\end{array}$ & $\begin{array}{l}-0.081 * * * \\
(0.029)\end{array}$ & $\begin{array}{c}-0.002 \\
(0.006)\end{array}$ & $\begin{array}{c}-0.054^{*} \\
(0.028)\end{array}$ & $\begin{array}{c}0.034 \\
(0.026)\end{array}$ & $\begin{array}{l}-0.085^{* * * *} \\
(0.024)\end{array}$ & $\begin{array}{c}-0.056^{* *} * \\
(0.025)\end{array}$ \\
\hline \multicolumn{8}{|l|}{ Controls } \\
\hline Latitude, rainfall, coast & Yes & Yes & & Yes & & Yes & \\
\hline Proportion sandy/barren & Yes & Yes & & Yes & & Yes & \\
\hline Number of districts & 163 & 163 & & 140 & & 163 & \\
\hline Number of native states & 71 & 71 & & 51 & & 71 & \\
\hline
\end{tabular}

Note: Robust standard errors in parentheses, corrected for clustering within native states.

*Significant at $10 \%$.

** Significant at $5 \%$.

*** Significant at $1 \%$

All regressions are for the post-1847 sample consisting of areas that were not annexed in or before 1847. Column 1 shows the base IV specifications from column 5 of table 8 . Data are missing for middle schools in Gujarat, high schools in Madhya Pradesh, and primary health subcenters in Karnataka. Data are missing for Assam in 1981 and Jammu and Kashmir in 1991.

difference with the native state rulers is that this class of landlords had no penalties for poor governance: they could be deprived of their privileges only if they failed to pay their revenue commitments to the British state.

The third institutional difference highlighted in section III related to the incentives of the administrators. The kings in native state areas had longer tenures than typical British administrators and were also liable to be deposed for poor governance. It is difficult to assess the empirical significance of these factors directly: the length of tenure of the ruler is highly correlated with the direct rule dummy (correlation $=0.90$ ), and all the kings were subject to the disciplining mechanism of potential British intervention. I document some evidence that poor governance in the past is predictive of future outcomes. I reran the IV regression and included a dummy variable for whether the ruler of that native state was ever deposed by the British for misrule. I find that this variable usually has a negative sign and is statistically significant for several public goods (table 12, column 4). The inclusion of this variable increases the size of the negative coefficients on the British dummy, which now represent the difference between the directly ruled areas and the areas with kings who were never deposed. In fact, there are no significant differences in public goods between British areas and native state areas where the ruler had been deposed for poor governance. ${ }^{29}$

This set of results strongly suggests that indicators of poor colonial period governance (whether the ruler was ever deposed in native state areas, whether the area had a landlord-based land revenue system in the directly ruled areas) have a persistent long-term impact on postcolonial outcomes. The overall result of the directly ruled areas lagging behind suggests that the institutional features of indirect rule favored better governance, on average, in the native states compared to the directly ruled areas.

\section{Conclusion}

In this paper, I use an unusual feature of British annexation policy to compare long-run outcomes of areas in India that were under direct British colonial rule with areas ruled by local kings under the indirect political control of the British. The annexation of areas where the local ruler died without a natural heir provides an exogenous determinant of whether an area came under direct British rule and therefore

\footnotetext{
29 The difference between the coefficient on the British dummy and the coefficient on the "ruler ever deposed" variable is never statistically significant.
} 
controls effectively for the selectivity in colonial annexation policy. The instrumental variable results indicate that directly ruled areas lag behind the availability of public goods such as schools, health facilities, and roads in the postcolonial period, with adverse consequences for development outcomes such as poverty and infant mortality rates.

The study highlights three key features relevant to understanding the impacts of history. First, colonial annexation policy was indeed very selective and tended to focus on areas with higher agricultural potential. This needs to be kept in mind for any future research on the impact of colonial policies and institutions.

Second, indicators of the quality of governance in the colonial period have persistent effects on long-term outcomes. In particular, the effect of direct versus indirect rule depends crucially on the incentives that local administrators faced. For India, the indirect rule exercised by landlords within the British Empire leads to worse outcomes, while the indirect rule exercised by hereditary kings results in better outcomes. The key difference is that kings were explicitly subject to being removed in cases of gross misrule, while landlords did not have this institutional constraint.

Third, the impact of colonial period governance becomes more muted over the longer term in the fact of explicit postcolonial policies designed to equalize access to schools, health centers, and roads. It is therefore possible to undo the effects of historical circumstances, though the results in this paper indicate that this process can take several decades.

\section{REFERENCES}

Acemoglu, Daron, Simon Johnson, and James A. Robinson, "The Colonial Origins of Comparative Development: An Empirical Investigation," American Economic Review 91:5 (2001), 1369-1401.

Allen, Charles, and Sharada Dwivedi, Lives of the Indian Princes (Mumbai: Eeshwar, 1998)

Angrist, Joshua, and Alan Krueger, "Empirical Strategies in Labor Economics," in Orley Ashenfelter and David Card (Eds.), The Handbook of Labor Economics (Amsterdam: North-Holland, 1999).

Ashton, S. R., British Policy towards the Indian States, 1905-1939 (London: Curzon Press, 1982).

Baden-Powell, B. H., The Land-Systems of British India (Oxford: Clarendon Press, 1892).

Bagchi, Amiya Kumar, The Political Economy of Underdevelopment (Cambridge: Cambridge University Press, 1982).

Banerjee, Abhijit, and Lakshmi Iyer, "History, Institutions and Economic Performance: The Legacy of Colonial Land Tenure Systems in India," American Economic Review 95:4 (2005), 1190-1213.

Banerjee, Abhijit, and Rohini Somanathan, "The Political Economy of Public Goods: Some Evidence from India," Journal of Development Economics 82:2 (2007), 287-314.

Berger, Daniel, "Taxes, Institutions and Local Governance: Evidence from a Natural Experiment in Colonial Nigeria," working paper (2008).

Berkowitz, Daniel, and Karen Clay, "Initial Conditions, Institutional Dynamics and Economic Performance: Evidence from the American States," mimeograph (2004).

Bertocchi, Graziella, and Fabio Canova, "Did Colonization Matter for Growth? An Empirical Exploration into the Historical Causes of Africa's Underdevelopment," European Economic Review 46 (2002), 1851-1871.

Bertrand, Marianne, Esther Duflo, and Sendhil Mullainathan, "How Much Should We Trust Differences-in-Differences Estimates?" Quarterly Journal of Economics 119:1 (2004), 249-275.
Chakrabarti, Jadab Chandra, The Native States of India (London: Luzac, 1896).

Das, S. K., Public Office, Private Interest: Bureaucracy and Corruption in India (New Delhi: Oxford University Press, 2001).

David, Saul, The Indian Mutiny: 1857 (London: Viking Penguin, 2002).

Do, Quy-Toan, and Lakshmi Iyer, "Land Titling and Rural Transition in Vietnam," Economic Development and Cultural Change 56:3 (2008), 531-579.

Engerman, Stanley L., and Kenneth L. Sokoloff, "Colonialism, Inequality and Long-Run Paths to Development," NBER working paper no. 11057 (2005).

Ferguson, Niall, Empire: The Rise and Demise of the British World Order and the Lessons for Global Power (New York: Basic Books, 2002).

Feyrer, James, and Bruce Sacerdote, "Colonialism and Modern Income: Islands as Natural Experiments," this REVIEW 91:2 (2009), 245262.

Frank, Andre Gunder, Dependent Accumulation and Underdevelopment (London: Macmillan, 1978).

Herbst, Jeffrey, States and Power in Africa: Comparative Lessons in Authority and Control (Princeton, NJ: Princeton University Press, 2000).

Huillery, Elise, "Colonialism and Development in the Former French West Africa: The Long-Term Impact of the Colonial Public Investments," working paper (2006).

Hunter, William Wilson, James Sutherland Cotton, Richard Burn, and William Stevenson Meyer (Eds.), The Imperial Gazetteer of India (Oxford: Clarendon Press, 1908).

Lal, Deepak, In Defense of Empires (Washington, DC: AEI Press, 2004).

LaPorta, Rafael, Florencio Lopez de Silanes, Andrei Shleifer, and Robert Vishny, "Law and Finance," Journal of Political Economy 106:6 (1998a), 1113-1155.

"The Quality of Government," Journal of Law, Economics and Organization 15:1 (1998b), 222-279.

Lee-Warner, William, The Life of the Marquis of Dalhousie K.T. (London: Macmillan, 1904).

The Native States of India (London: Macmillan, 1910).

Menon, A. Sreedhara, A Survey of Kerala History (Kottayam: National Book Stall, 1967).

Mukherjee, Tapan, "Theory of Economic Drain: Impact of British Rule on the Indian Economy, 1840-1900," in Kenneth Boulding and Tapan Mukherjee (Eds.), Economic Imperialism: A Book of Readings (Ann Arbor: University of Michigan Press, 1972).

Nunn, Nathan, "The Long-Term Effects of Africa's Slave Trades," Quarterly Journal of Economics 123 (2008), 139-176.

Potter, David C., India's Political Administrators: From ICS to the IAS (New Delhi: Oxford University Press, 1996).

Rahim, M. A., Lord Dalhousie's Administration of the Conquered and Annexed States (New Delhi: S. Chand, 1963).

Rauch, James, "Bureaucracy, Infrastructure and Economic Growth: Evidence from U.S. Cities during the Progressive Era," American Economic Review 85 (1995), 968-979.

Richter, William, "Electoral Patterns in Post-Princely India," in Myron Weiner and John Osgood Field (Eds.), Electoral Politics in the Indian States: Three Disadvantaged Sectors (Delhi: Manohar Book Service, 1975).

Roy, Tirthankar, The Economic History of India, 1857-1947 (New Delhi: Oxford University Press, 2000).

"Economic History and Modern India: Redefining the Link," Journal of Economic Perspectives 16:3 (2002), 109-130.

Spear, T. G. Percival, "India and European Expansion, c.1500-1858," Encyclopedia Britannica (2002).

Topalova, Petia, "Trade Liberalization, Poverty and Inequality: Evidence from Indian Districts," NBER working paper no. 11614 (2005).

Vanneman, Reeve, and Douglas Barnes, "Indian District Database, 19611991," machine-readable data file and codebook (College Park, MD: Center on Population, Gender, and Social Inequality, 2000). Available online at http://www.bsos.umd.edu/socy/vanneman/districts/ index.html.

Zhao, Zhong, "Using Matching to Estimate Treatment Effects: Data Requirements, Matching Metrics, and Monte Carlo Evidence," this REVIEW 86:1 (2004), 91-107. 
DATA APPENDIX

A. Major Native States, 1947

\begin{tabular}{|c|c|c|c|c|c|c|}
\hline Native State & $\begin{array}{l}\text { Number of Guns } \\
\text { in Salute }\end{array}$ & $\begin{array}{c}\text { Date of Treaty } \\
\text { with British }\end{array}$ & $\begin{array}{c}\text { Area } \\
\text { (sq. miles) }\end{array}$ & $\begin{array}{l}\text { Population } \\
\text { (1896) }\end{array}$ & $\begin{array}{l}\text { Religion } \\
\text { of Ruler }\end{array}$ & $\begin{array}{c}\text { Number of Modern } \\
\text { Districts }\end{array}$ \\
\hline Baroda & 21 & 1802 & 8,570 & $2,185,005$ & Hindu & 3 \\
\hline Gwalior & 21 & 1781 & 29,046 & $3,115,857$ & Hindu & 9 \\
\hline Hyderabad & 21 & 1759 & 98,000 & $9,845,594$ & Muslim & 20 \\
\hline Kashmir & 21 & 1846 & 80,000 & $1,534,972$ & Hindu & 14 \\
\hline Mysore & 21 & 1799 & 24,723 & $4,186,188$ & Hindu & 10 \\
\hline Bhopal & 19 & 1817 & 6,873 & 954,901 & Muslim & 3 \\
\hline Indore & 19 & 1805 & 8,400 & $1,054,237$ & Hindu & 3 \\
\hline Kolhapur & 19 & 1766 & 2,816 & 800,189 & Hindu & 1 \\
\hline Travancore & 19 & 1723 & 6,730 & $2,401,158$ & Hindu & 6 \\
\hline Udaipur & 19 & 1818 & 12,670 & $1,494,220$ & Hindu & 3 \\
\hline Bharatpur & 17 & 1803 & 1,974 & 645,540 & Hindu & 1 \\
\hline Bikaner & 17 & 1818 & 22,340 & 509,021 & Hindu & 3 \\
\hline Bundi & 17 & 1818 & 2,300 & 254,701 & Hindu & 1 \\
\hline Cochin & 17 & 1791 & 1,361 & 600,278 & Hindu & 3 \\
\hline Jaipur & 17 & 1818 & 14,465 & $2,534,357$ & Hindu & 3 \\
\hline Jodhpur & 17 & 1818 & 37,000 & $1,750,403$ & Hindu & 5 \\
\hline Karauli & 17 & 1817 & 1,208 & 148,670 & Hindu & 1 \\
\hline Kota & 17 & 1817 & 3,797 & 517,275 & Hindu & 1 \\
\hline Kutch & 17 & 1809 & 6,500 & 512,084 & Hindu & 1 \\
\hline Patiala & 17 & 1809 & 5,887 & $1,467,433$ & Sikh & 5 \\
\hline Rewa & 17 & 1812 & 1,000 & $1,305,124$ & Hindu & 4 \\
\hline Tonk & 17 & 1817 & 2,509 & 338,029 & Muslim & 1 \\
\hline Alwar & 15 & 1803 & 3,024 & 682,926 & Hindu & 1 \\
\hline Banswara & 15 & 1818 & 1,300 & 152,045 & Hindu & 1 \\
\hline Datia & 15 & 1804 & 836 & 182,598 & Hindu & 1 \\
\hline Dewas & 15 & 1818 & 2,566 & 142,162 & Hindu & 1 \\
\hline Dhar & 15 & 1819 & 1,740 & 149,244 & Hindu & 1 \\
\hline Dholpur & 15 & 1779 & 1,200 & 249,657 & Hindu & 1 \\
\hline Dungarpur & 15 & 1818 & 1,000 & 153,381 & Hindu & 1 \\
\hline Idar & 15 & 1812 & 4,966 & 258,429 & Hindu & 1 \\
\hline Jaisalmer & 15 & 1818 & 16,447 & 108,143 & Hindu & 1 \\
\hline Kishangarh & 15 & 1818 & 724 & 112,633 & Hindu & 1 \\
\hline Orchha & 15 & 1812 & 2,000 & 311,514 & Hindu & 1 \\
\hline Partabgarh & 15 & 1818 & 1,460 & 79,568 & Hindu & 1 \\
\hline Rampur & 15 & 1794 & 899 & 541,914 & Muslim & 1 \\
\hline Sirohi & 15 & 1823 & 3,020 & 142,903 & Hindu & 1 \\
\hline Bhavnagar & 13 & 1807 & 2,860 & 400,323 & Hindu & 1 \\
\hline Cooch Behar & 13 & 1773 & 1,307 & 602,624 & Hindu & 1 \\
\hline Dhrangadhra & 13 & 1807 & 1,142 & 99,686 & Hindu & 1 \\
\hline Jaora & 13 & 1818 & 872 & 108,343 & Muslim & 2 \\
\hline Jhalawar & 13 & 1838 & 2,694 & 340,488 & Hindu & 1 \\
\hline Jind & 13 & 1809 & 1,323 & 294,862 & Sikh & 1 \\
\hline Junagadh & 13 & 1807 & 3,283 & 387,499 & Muslim & 2 \\
\hline Kapurthala & 13 & 1846 & 620 & 252,617 & Sikh & 1 \\
\hline Nabha & 13 & 1809 & 928 & 261,824 & Sikh & 1 \\
\hline Nawanagar & 13 & 1807 & 1,379 & 316,147 & Hindu & 1 \\
\hline Palanpur & 13 & 1809 & 3,150 & 234,402 & Muslim & 1 \\
\hline Porbandar & 13 & 1807 & 636 & 71,072 & Hindu & 1 \\
\hline Rajpipla & 13 & 1821 & 1,514 & 59,834 & Hindu & 1 \\
\hline Ratlam & 13 & 1819 & 729 & 87,314 & Hindu & 1 \\
\hline Ajaigarh & 11 & 1807 & 802 & 81,454 & Hindu & 1 \\
\hline Ali Rajpur & 11 & 1818 & 836 & 56,287 & Hindu & 1 \\
\hline Barwani & 11 & 1818 & 1,362 & 56,445 & Hindu & 1 \\
\hline Bijawar & 11 & 1811 & 973 & 113,285 & Hindu & 1 \\
\hline Bilaspur & 11 & 1846 & & & Hindu & 1 \\
\hline Cambay & 11 & 1771 & 350 & 86,074 & Muslim & 1 \\
\hline Chamba & 11 & 1846 & 3,180 & 115,773 & Hindu & 1 \\
\hline Charkhari & 11 & 1804 & 788 & 143,015 & Hindu & 1 \\
\hline Chhatarpur & 11 & 1806 & 1,169 & 164,376 & Hindu & 1 \\
\hline Faridkot & 11 & 1809 & 612 & 97,034 & Hindu & 1 \\
\hline Gondal & 11 & 1807 & 687 & 135,604 & Hindu & 1 \\
\hline Jhabua & 11 & 1821 & 1,336 & 147,100 & Hindu & 1 \\
\hline Mandi & 11 & 1846 & 1,000 & 147,017 & Hindu & 1 \\
\hline Morvi & 11 & 1807 & 821 & 90,016 & Hindu & 1 \\
\hline Narsinghgarh & 11 & 1818 & 623 & 112,427 & Hindu & 1 \\
\hline Panna & 11 & 1807 & 2,568 & 227,306 & Hindu & 1 \\
\hline Pudukkottai & 11 & 1803 & 1,101 & 302,127 & Hindu & 1 \\
\hline
\end{tabular}




\begin{tabular}{|c|c|c|c|c|c|c|}
\hline Native State & $\begin{array}{l}\text { Number of Guns } \\
\text { in Salute }\end{array}$ & $\begin{array}{l}\text { Date of Treaty } \\
\text { with British }\end{array}$ & $\begin{array}{c}\text { Area } \\
\text { (sq. miles) }\end{array}$ & $\begin{array}{l}\text { Population } \\
\text { (1896) }\end{array}$ & $\begin{array}{l}\text { Religion } \\
\text { of Ruler }\end{array}$ & $\begin{array}{l}\text { Number of Modern } \\
\text { Districts }\end{array}$ \\
\hline Radhanpur & 11 & 1813 & 1,150 & 98,129 & Muslim & 1 \\
\hline Rajgarh & 11 & 1818 & 655 & 117,533 & Hindu & 1 \\
\hline Sailana & 11 & 1819 & 114 & 29,723 & Hindu & 1 \\
\hline Sirmur & 11 & 1815 & 1,077 & 112,371 & Hindu & 1 \\
\hline Tehri Garhwal & 11 & 1820 & 4,180 & 199,836 & Hindu & 3 \\
\hline Wankaner & 11 & 1807 & 376 & 30,491 & Hindu & 1 \\
\hline Balasinor & 9 & & 189 & 46,328 & Muslim & 1 \\
\hline Bansda & 9 & 1802 & 384 & 34,122 & Hindu & 1 \\
\hline Chhota Udepur & 9 & 1822 & 873 & 71,218 & Hindu & 1 \\
\hline Dharampur & 9 & & 794 & 101,289 & Hindu & 1 \\
\hline Dhrol & 9 & & 400 & 21,177 & Hindu & 1 \\
\hline Kalahandi & 9 & 1829 & & & & 1 \\
\hline Khilchipur & 9 & 1818 & 273 & 36,125 & Hindu & 1 \\
\hline Limbdi & 9 & & 344 & 40,186 & Hindu & 1 \\
\hline Maihar & 9 & & 400 & 71,709 & Hindu & 1 \\
\hline Mayurbhanj & 9 & 1829 & 4,243 & 385,737 & Hindu & 2 \\
\hline Nagod & 9 & 1809 & 450 & 79,629 & Hindu & 1 \\
\hline Rajkot & 9 & 1807 & 283 & 46,540 & Hindu & 1 \\
\hline Sangli & 9 & & 896 & 196,832 & Hindu & 1 \\
\hline Savantwadi & 9 & 1730 & 900 & 174,433 & Hindu & 1 \\
\hline Bashahr & 9 & 1815 & 3,320 & 64,345 & Hindu & 1 \\
\hline Dhenkanal & & 1829 & 1,463 & 208,316 & & 1 \\
\hline Keunjhar & & 1829 & 3,096 & 215,612 & Hindu & 1 \\
\hline Raigarh & & & 1,486 & 128,943 & & 1 \\
\hline Sarguja & & 1817 & 6,055 & 270,311 & Hindu & 1 \\
\hline
\end{tabular}

Note: Native states listed in decreasing order of the number of guns in ceremonial salute. Number of modern districts refers to the number of districts containing areas from the native state. Several modern districts contain areas from more than one native state. Native state boundaries may or may not coincide with modern district boundaries.

\section{B. Data Sources}

Postindependence data

- Data on district geography, crop areas, yields, irrigation, fertilizer use, adoption of high-yielding varieties: India Agriculture and Climate Data Set (World Bank), http://www-esd.worldbank.org/indian/home.cfm

- Public goods at village level, 1961, 1981, 1991: Census reports

- District-level data on population, literacy, occupation classes, proportion of scheduled castes, and so on: Indian Database Project by Vanneman and Barnes (2000)

- Indian District Data, 1961-1991: Machine-readable data file and codebook, Center on Population, Gender, and Social Inequality, College Park, Maryland. URL: http://www.bsos.umd.edu/socy/vanneman/districts/index.html

Matching postindependence districts with British districts and native states

- Districts and maps of British India: Baden-Powell (1892)

- Districts and maps of modern India: http://www.mapsofindia.com

- District gazetteers (various issues)

Historical data

- Area and revenue of native states: Chakrabarti (1896) and Hunter et al. (1908)

- Details of death of kings in native states: District gazetteers; Lee-Warner (1904); Menon (1967); http://www.dreamwater.net/regiment/RoyalArk/India/ India.htm; http://www.uq.net.au/ zzhsoszy/ips

- Literacy and infant mortality in earlier periods: District gazetteers

- District-level poverty and inequality: Topalova (2005)

\section{Details of Native States Where Rulers Died without Natural Heir, 1848-1856}

\begin{tabular}{|c|c|c|}
\hline $\begin{array}{l}\text { Native } \\
\text { State }\end{array}$ & $\begin{array}{c}\text { Year of Death } \\
\text { of Ruler }\end{array}$ & Details \\
\hline \multicolumn{3}{|c|}{ Major kingdoms annexed by Lord Dalhousie } \\
\hline Satara & 1848 & $\begin{array}{l}\text { State created in } 1818 \text { for defeated Maratha ruler; ruler deposed in favor of his brother in } 1842 \text {; state annexed by lapse in } \\
1848 \text {. }\end{array}$ \\
\hline Sambalpur & 1849 & $\begin{array}{l}\text { Part of Bhonsla kingdom originally; handed over to a local ruler, Maharaja Sahi, in } 1818 \text { and to his queen on his death in } \\
\text { 1827. Kingdom given to relative Narayan Singh in } 1833 \text { after local insurrection. Annexed by Doctrine of Lapse in } \\
1849 \text { when ruler died without heir. }\end{array}$ \\
\hline Jhansi & 1853 & $\begin{array}{l}\text { First treaty of protection with British in 1804; ruler died without heir in } 1835 \text { and in } 1838 \text { but successors installed by } \\
\text { British and state not annexed; state annexed by Lord Dalhousie due to lapse in } 1853 \text {. }\end{array}$ \\
\hline
\end{tabular}




\begin{tabular}{|c|c|c|}
\hline $\begin{array}{l}\text { Native } \\
\text { State }\end{array}$ & $\begin{array}{l}\text { Year of Death } \\
\text { of Ruler }\end{array}$ & Details \\
\hline Nagpur & 1854 & $\begin{array}{l}\text { Bhonsla ruler defeated in 1818, and kingdom put under British administration until 1830; Taken over by Doctrine of } \\
\text { Lapse in } 1854 \text { after death of ruler in December } 1853 \text {. }\end{array}$ \\
\hline \multicolumn{3}{|c|}{ Major kingdoms where rulers died without heir in 1848-1856 but which were not annexed } \\
\hline Orchha & 1852 & $\begin{array}{l}\text { Lord Dalhousie did not annex on grounds of Orchha being a nontributary state; also the British had a prior agreement } \\
\text { with the queen (made in 1841), which allowed her to adopt an heir. }\end{array}$ \\
\hline Karauli & 1853 & $\begin{array}{l}\text { Ruler died without heir in 1853; Lord Dalhousie recommended annexation but was disallowed by the East India } \\
\text { Company's Court of Directors. }\end{array}$ \\
\hline Chhatarpur & 1854 & Ruler died without heir in 1854 and was succeeded by his nephew. \\
\hline Ajaigarh & 1855 & $\begin{array}{l}\text { Ruler died without heir in } 1855 \text {, and the state was annexed by Lord Dalhousie. Royal family remained loyal to the British } \\
\text { during the } 1857 \text { revolt, and the state was returned to an adopted heir by Lord Canning in } 1857 \text {. }\end{array}$ \\
\hline
\end{tabular}

\section{Table Appendix}

Table A.1.-Impact of Colonial Rule on Structural Change

\begin{tabular}{|c|c|c|c|c|c|c|c|c|}
\hline & \multicolumn{2}{|c|}{$\begin{array}{l}\text { Fraction of Workforce } \\
\text { in Manufacturing }\end{array}$} & \multicolumn{2}{|c|}{$\begin{array}{c}\text { Fraction of Rural } \\
\text { Workforce in } \\
\text { Manufacturing }\end{array}$} & \multicolumn{2}{|c|}{$\begin{array}{l}\text { Fraction of Workforce } \\
\text { in Farming }\end{array}$} & \multicolumn{2}{|c|}{$\begin{array}{c}\text { Fraction of Rural } \\
\text { Workforce in Farming }\end{array}$} \\
\hline & $\begin{array}{l}\text { 1961-1991 } \\
\text { OLS }\end{array}$ & $\begin{array}{l}\text { 1961-1991 } \\
\text { IV }\end{array}$ & $\begin{array}{l}1991 \text { Only } \\
\text { OLS }\end{array}$ & $\begin{array}{l}1991 \text { Only } \\
\text { IV }\end{array}$ & $\begin{array}{l}\text { 1961-1991 } \\
\text { OLS }\end{array}$ & $\begin{array}{l}\text { 1961-1991 } \\
\text { IV }\end{array}$ & $\begin{array}{l}1991 \text { Only } \\
\text { OLS }\end{array}$ & $\begin{array}{l}1991 \text { Only } \\
\text { IV }\end{array}$ \\
\hline British dummy & $\begin{array}{c}0.004 \\
(0.006)\end{array}$ & $\begin{array}{r}-0.015 \\
(0.010)\end{array}$ & $\begin{array}{r}-0.001 \\
(0.005)\end{array}$ & $\begin{array}{r}-0.005 \\
(0.007)\end{array}$ & $\begin{array}{r}-0.001 \\
(0.020)\end{array}$ & $\begin{array}{c}0.052 \\
(0.032)\end{array}$ & $\begin{array}{c}0.007 \\
(0.019)\end{array}$ & $\begin{array}{c}0.054 * \\
(0.032)\end{array}$ \\
\hline \multicolumn{9}{|l|}{ Controls } \\
\hline Latitude, rainfall, coast & Yes & Yes & Yes & Yes & Yes & Yes & Yes & Yes \\
\hline Proportion sandy/barren & Yes & Yes & Yes & Yes & Yes & Yes & Yes & Yes \\
\hline Year fixed effects & Yes & Yes & & & Yes & Yes & & \\
\hline Number of districts & 1,245 & 620 & 313 & 155 & 1,245 & 620 & 313 & 155 \\
\hline Number of native states & 94 & 70 & 94 & 70 & 94 & 70 & 94 & 70 \\
\hline
\end{tabular}

Note: Robust standard errors in parentheses, corrected for clustering within native states.

*Significant at $10 \%$.

Instrument is a dummy for whether the ruler died without an heir in the period 1848-1856. Data are for the census years 1961, 1971, 1981, and 1991.

Table A.2.-Does the Religion of the Ruler MaKe a Difference?

\begin{tabular}{|c|c|c|c|}
\hline & \multicolumn{3}{|c|}{ Coefficient } \\
\hline & British Dummy & Muslim Ruler & Sikh Ruler \\
\hline \multicolumn{4}{|c|}{ Dependent variables: Proportion of villages having public goods (mean of 1981 and 1991 data) } \\
\hline \multirow[t]{2}{*}{ Primary school } & 0.028 & $0.085 *$ & $0.295 * * *$ \\
\hline & $(0.039)$ & $(0.048)$ & $(0.047)$ \\
\hline \multirow[t]{2}{*}{ Middle school } & $-0.095^{*}$ & -0.028 & $0.195^{* * *} *$ \\
\hline & $(0.049)$ & $(0.045)$ & $(0.039)$ \\
\hline \multirow[t]{2}{*}{ High school } & -0.072 & -0.036 & $0.149 * * *$ \\
\hline & $(0.061)$ & $(0.060)$ & $(0.034)$ \\
\hline \multirow[t]{2}{*}{ Primary health center } & $-0.036^{*}$ & -0.014 & $0.046^{* * *}$ \\
\hline & $(0.019)$ & $(0.017)$ & $(0.011)$ \\
\hline \multirow[t]{2}{*}{ Primary health subcenter } & $-0.063 * *$ & -0.022 & 0.054 \\
\hline & $(0.027)$ & $(0.019)$ & $(0.054)$ \\
\hline \multirow[t]{2}{*}{ Canals } & -0.053 & $-0.031^{*}$ & 0.025 \\
\hline & $(0.033)$ & $(0.018)$ & $(0.048)$ \\
\hline \multirow[t]{2}{*}{ Roads } & $-0.186^{* * *}$ & -0.021 & $0.634 * * *$ \\
\hline & $(0.069)$ & $(0.048)$ & $(0.092)$ \\
\hline \multirow[t]{2}{*}{ Combined public goods } & $-0.074 * * *$ & -0.013 & $0.200 * * *$ \\
\hline & $(0.028)$ & $(0.025)$ & $(0.042)$ \\
\hline \multicolumn{4}{|l|}{ Controls } \\
\hline \multicolumn{2}{|l|}{ Latitude, rainfall, coast } & Yes & \\
\hline \multicolumn{2}{|l|}{ Proportion sandy/barren } & Yes & \\
\hline \multicolumn{2}{|l|}{ Number of observations } & 374 & \\
\hline \multicolumn{2}{|l|}{ Number of native states } & 93 & \\
\hline
\end{tabular}

Note: Robust standard errors in parentheses, corrected for clustering within native states.

*Significant at $10 \%$.

**Significant at $5 \%$.

*** Significant at $1 \%$

Data are missing for middle schools in Gujarat, high schools in Madhya Pradesh, and primary health subcenters in Karnataka. Data are missing for Assam in 1981 and Jammu and Kashmir in 1991. 
Table A.3.- Is There Convergence in Public Goods Provision?

\begin{tabular}{|c|c|c|c|c|}
\hline & \multicolumn{2}{|c|}{ OLS } & \multicolumn{2}{|c|}{ IV } \\
\hline & \multicolumn{2}{|c|}{ Coefficient } & \multicolumn{2}{|c|}{ Coefficient } \\
\hline & British Dummy & 1961 Level & British Dummy & 1961 Level \\
\hline \multirow[t]{2}{*}{ Primary school } & 0.016 & $0.239 * *$ & $0.074 * *$ & $0.491 * * *$ \\
\hline & $(0.024)$ & $(0.095)$ & $(0.032)$ & $(0.058)$ \\
\hline \multirow[t]{2}{*}{ Middle school } & -0.010 & $0.734 * * *$ & $-0.063^{*}$ & $0.941 * * *$ \\
\hline & $(0.028)$ & $(0.094)$ & $(0.034)$ & $(0.174)$ \\
\hline \multirow[t]{2}{*}{ High school } & -0.014 & $1.528 * * *$ & -0.011 & $1.464 * * *$ \\
\hline & $(0.011)$ & $(0.125)$ & $(0.017)$ & $(0.113)$ \\
\hline \multirow[t]{2}{*}{ Primary health center } & $-0.024 * *$ & $0.872 * * *$ & $-0.045^{*}$ & $1.470 * * *$ \\
\hline & $(0.011)$ & $(0.301)$ & $(0.024)$ & $(0.157)$ \\
\hline \multirow[t]{2}{*}{ Canals } & 0.021 & 0.139 & -0.015 & $6.645^{*}$ \\
\hline & $(0.015)$ & $(0.242)$ & $(0.049)$ & $(3.718)$ \\
\hline \multirow[t]{2}{*}{ Roads } & 0.062 & $0.355^{* * *}$ & $-0.061 *$ & $0.242 * * *$ \\
\hline & $(0.039)$ & $(0.081)$ & $(0.036)$ & $(0.077)$ \\
\hline \multicolumn{5}{|l|}{ Controls } \\
\hline Latitude, rainfall, coast & \multicolumn{2}{|c|}{ Yes } & \multicolumn{2}{|c|}{ Yes } \\
\hline Proportion sandy/barren & \multicolumn{2}{|c|}{ Yes } & \multicolumn{2}{|c|}{ Yes } \\
\hline Number of districts & \multicolumn{2}{|c|}{225} & \multicolumn{2}{|c|}{124} \\
\hline Number of native states & \multicolumn{2}{|c|}{78} & \multicolumn{2}{|c|}{60} \\
\hline
\end{tabular}

Note: Robust standard errors in parentheses, corrected for clustering within native states.

*Significant at $10 \%$.

*** Significant at $5 \%$.

Data on rural health centers and canals are missing for UP, Tamil Nadu, Rajasthan, Orissa, and Maharashtra. Data on primary schools, middle schools, and dispensaries are missing for Uttar Pradesh. Data on middle schools, canals, and roads are missing for West Bengal. Data on roads are missing for Punjab and Rajasthan.

TABle A.4.-Political Participation And Competition

\begin{tabular}{|c|c|c|c|c|c|c|c|c|}
\hline & \multicolumn{2}{|c|}{ Voter Turnout in State } & \multicolumn{2}{|c|}{ Voter Turnout in State } & \multicolumn{2}{|c|}{ Winning Margin (\%) } & \multicolumn{2}{|c|}{ Winning Margin (\%) } \\
\hline & $\begin{array}{l}\text { 1960s } \\
\text { OLS }\end{array}$ & $\begin{array}{l}\text { 1960s } \\
\text { IV }\end{array}$ & $\begin{array}{l}\text { Post-1980 } \\
\text { OLS }\end{array}$ & $\begin{array}{c}\text { Post-1980 } \\
\text { IV }\end{array}$ & $\begin{array}{l}\text { 1960s } \\
\text { OLS }\end{array}$ & $\begin{array}{l}\text { 1960s } \\
\text { IV }\end{array}$ & $\begin{array}{l}\text { Post-1980 } \\
\text { OLS }\end{array}$ & $\begin{array}{c}\text { Post-1980 } \\
\text { IV }\end{array}$ \\
\hline British dummy & $\begin{array}{l}0.015 \\
(0.031)\end{array}$ & $\begin{array}{r}-0.050 \\
(0.063)\end{array}$ & $\begin{array}{r}-0.015 \\
(0.019)\end{array}$ & $\begin{array}{c}-0.013 \\
(0.028)\end{array}$ & $\begin{array}{c}0.003 \\
(0.019)\end{array}$ & $\begin{array}{c}0.072 \\
(0.077)\end{array}$ & $\begin{array}{r}-0.003 \\
(0.006)\end{array}$ & $\begin{array}{c}0.006 \\
(0.012)\end{array}$ \\
\hline $\begin{array}{l}\text { Mean of dependent variable } \\
\text { Controls }\end{array}$ & 0.56 & 0.55 & 0.60 & 0.60 & 0.19 & 0.19 & 0.15 & 0.15 \\
\hline $\begin{array}{l}\text { Latitude, rainfall, coast } \\
\text { Proportion sandy/barren } \\
\text { Number of districts } \\
\text { Number of native states }\end{array}$ & $\begin{array}{l}\text { Yes } \\
\text { Yes } \\
164\end{array}$ & $\begin{array}{l}\text { Yes } \\
\text { Yes } \\
102\end{array}$ & $\begin{array}{l}\text { Yes } \\
\text { Yes } \\
314\end{array}$ & $\begin{array}{l}\text { Yes } \\
\text { Yes } \\
135\end{array}$ & $\begin{array}{l}\text { Yes } \\
\text { Yes } \\
164\end{array}$ & $\begin{array}{l}\text { Yes } \\
\text { Yes } \\
102\end{array}$ & $\begin{array}{l}\text { Yes } \\
\text { Yes } \\
314\end{array}$ & $\begin{array}{l}\text { Yes } \\
\text { Yes } \\
135\end{array}$ \\
\hline $\begin{array}{l}\text { Note: Robust standard errors in parenthe } \\
\text { Voter turnout is measured as the fraction } \\
\text { ost-1980 data include elections between } 1 \\
\text { Madhya Pradesh, Maharashtra, Orissa, and }\end{array}$ & $\begin{array}{l}\text { rrected for } \\
\text { ds who actu } \\
2004.196\end{array}$ & $\begin{array}{l}\text { ig within } \\
\text { ed in the } \\
\text { are for the }\end{array}$ & $\begin{array}{l}\text { ates. } \\
\text { Winning marg } \\
\text { ction in the sta } \\
\text {-IMPACT }\end{array}$ & $\begin{array}{l}\text { nputed as the c } \\
\text { 1959. This reg }\end{array}$ & $\begin{array}{l}\text { e between } \\
\text { is based or }\end{array}$ & share of th & $\begin{array}{l}\text { g candidate } \\
\text { hra Pradesh, }\end{array}$ & $\begin{array}{l}\text { nner-up can } \\
\text { Karnataka, K }\end{array}$ \\
\hline
\end{tabular}

Coefficient on Dummy for Cultivator-Based Land Tenure System

British Empire OLS Native States OLS

(1)

(2)

$\begin{array}{lcr}\text { Dependent variables: Proportion of villages having public goods (mean of } 1981 \text { and } 1991 \text { data) } \\ \text { Primary school } & 0.049 & 0.058 \\ \text { Middle school } & (0.044) & (0.054) \\ & 0.106 * * * & 0.011 \\ \text { High school } & (0.035) & (0.049) \\ & 0.070^{* *} & (0.035 \\ \text { Primary health center } & (0.028) & -0.012 \\ & 0.028^{* * *} & (0.012) \\ \text { Primary health subcenter } & (0.009) & 0.008 \\ & 0.032 & (0.018) \\ \text { Canals } & (0.023) & -0.009 \\ & 0.004 & (0.026) \\ \text { Roads } & (0.014) & 0.129 \\ & 0.263 * * * & (0.101) \\ \text { Combined public goods } & (0.059) & 0.023 \\ \text { Controls } & 0.080^{* * *} & (0.034) \\ \text { Latitude, rainfall, coast } & (0.026) & \text { Yes } \\ \text { Proportion sandy/barren } & & \text { Yes } \\ \text { Number of districts } & \text { Yes } & 105 \\ \text { Number of native states } & 234 & 43\end{array}$

Note: Robust standard errors in parentheses, corrected for clustering within native states.

**** Significant at $1 \%$.

Data are missing for middle schools in Gujarat, high schools in Madhya Pradesh, and primary health subcenters in Karnataka. Data are missing for Assam in 1981 and Jammu and Kashmir in 1991. 